\title{
Two-Dimensional Modeling of the Influence of Underground Mining Direction on Slope Stability in Coordinated Open-Pit and Underground Mining
}

Bowen Liu ( $\sim$ lang860930@126.com )

China University of Mining and Technology - Beijing Campus https://orcid.org/0000-0002-8632-5257

Zhenwei Wang

North China University of Technology

Xinpin Ding

China Coal Research Institute

Zhitao Wang

North China University of Technology

Bin Li

North China University of Technology

\section{Research}

Keywords: Coordinated open-pit and underground mining, Mining direction, Underground mining disturbance, Slope-deformation destruction

Posted Date: February 23rd, 2021

DOI: https://doi.org/10.21203/rs.3.rs-228554/v1

License: (c) (1) This work is licensed under a Creative Commons Attribution 4.0 International License.

Read Full License 


\title{
Two-dimensional modeling of the influence of underground mining direction on slope stability in coordinated open-pit and underground mining
}

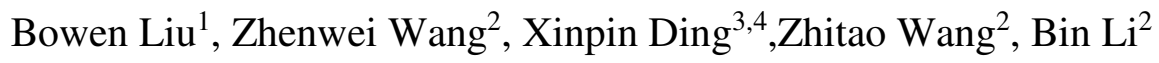 \\ ${ }^{1}$ School of Energy and Mining Engineering, China University of Mining and Technology (Beijing), Beijing 100083, \\ China \\ ${ }^{2}$ School of Civil Engineering, North China University of Technology, Beijing 100144, China \\ ${ }^{3}$ China Coal Research Institute, Beijing 100013, China \\ ${ }^{4}$ CCTEG Beijing Academy of Land Renovation and Ecological Restoration Technology Co.,Ltd. Beijing 100013, \\ China
}

\begin{abstract}
Under a background of coordinated open-pit and underground mining engineering practice in the Pingshuo mining area, a combination of numerical simulations and similar-model experiments was used to study the influence of the underground mining direction on slope deformation in two dimensions. The results show that the disturbance caused by inverse-slope mining is more obvious than that caused by along-slope mining. Underground mining presents an asymmetric influence on the open-pit slope; the slope rock mass on the open-off cut side is disturbed more than that on the coal-wall side. Compared with the slope in front of the advancing direction of the underground mining face, the degree of rock-mass damage and stress concentration of the slope of the open-off cut side are more serious. As such, in coordinated open-pit and underground mining practice, an along-slope mining direction is recommended to reduce adverse effects on slope stability and improve the recovery rate of coal resources.
\end{abstract}

Keywords Coordinated open-pit and underground mining · Mining direction · Underground mining disturbance $\cdot$ Slope-deformation destruction

\section{Declarations}

\section{Funding}

This work was supported by the General Programs of the National Natural Science Foundation of China (grant no. 51774184).

\section{Conflicts of interest/Competing interests}

Not applicable

Availability of data and material

Not applicable

\section{Code availability}

Not applicable

\section{Authors' contributions}




\section{Introduction}

As a new mining method, combining open-pit with underground mining can achieve the complementary advantages of both methods and reduce the waste of resources (Zhu et al. 2009). It is a favorable choice for minimizing the environmental damage caused by mining of shallow-buried resources, and it is being gradually adopted in major mining areas. The strata movement caused by the intersection of these two mining methods can result in their mutual interference, and this can seriously affect the slope stability of the open pit (Zhou et al. 2012). Therefore, it is of great theoretical significance to discuss the influence of mining subsidence on slope deformation and failure of openpit mines under in such combined mining (Liu et al. 2007).

There are few studies in combined surface and underground mining abroad. However, in recent years, many studies have been carried out in China in the mechanism of deformation and failure and the optimization of boundary parameters of open pit mining slope, and many important results have been obtained (Zhu et al. 2010; Liu 2008; Sun and Cai 2000; Sun 1999; Liu 2008; Lan et al. 2007; Zhu et al. 2009). However, there has been little research in the influence of different underground mining directions on slope-deformation failure in combined mining. Improving combined mining technology and practice is therefore of great scientific significance.

\section{Project overview}

To reduce production costs and improve economic benefits, the Pingshuo mining area began to transform from single open-pit mining to coordinated open-pit and underground mining in 2002. A coordinated open-pit mining pattern represented by the Antaibao open-pit mine, the Anjialing openpit mine, the No.1 mine, and the No.2 mine has been formed. Figure 1 shows the stratigraphic structure of the coordinated open-pit and underground area, with horizontal and slow-wave bedding. The main mining areas of No. 2 mine are the No.4 and 9 coal seams. The thickness of the No.4 coal seam is generally $5.10-15.90 \mathrm{~m}$, with an average of $10.50 \mathrm{~m}$. The thickness of the No.9 coal seam is generally $6.72-18.60 \mathrm{~m}$, with an average of $12.80 \mathrm{~m}$. The mining method is comprehensive mechanized top-coal caving mining, and the roof is managed by all caving methods. The No.4 and 9 coal working faces are arranged side by side in the north-south direction. The opening cut is located at the lower part of the southern end of the Antaibao open-pit mine, and the stopping line and main roadway are located at the lower part of the north end of Anjialing open-pit mine (Fig. 1).

\section{Calculation model and simulation scheme}

To study the influence of the mining direction on the slope stability of coordinated open-pit and underground mining and determine a reasonable coal mining direction, the Realistic Failure Process Analysis (RFPA) software package (Mechsoft Technology, USA) was used to simulate the destruction and movement of slope rock mass in the B906 working face of Jinggong No. 2 mine. Then, the Universal Distinct Element Code (UDEC, Itasca International, Inc., USA) was used to simulate the stress distribution of the slope rock mass. The simulation process adopted two schemes: inverse-slope and along-slope mining of the B906 working face. The physical and mechanical properties of the rock and soil that were used in the calculations are shown in Table 1.

\subsection{RFPA model and simulation}

The stratum structure of the P1 section (Fig. 1) was simplified to establish an RFPA numerical simulation. The model was $900 \mathrm{~m}$ long, $260 \mathrm{~m}$ high, and had a total of 58500 primitives of size $2 \times 2$ $\mathrm{m}$. The elastic modulus, uniaxial compressive strength, and other parameters of the elements were randomly distributed according to a Weibull function to simulate the heterogeneity and anisotropy of rock materials. The boundary conditions of the model were a fixed bottom, a free top, and constrained horizontal displacement of the left and right sides. In the numerical calculations, the Mohr-Coulomb strength criterion was adopted for each rock stratum. To simplify the calculations, the plane-strain model assumption was applied.

The excavation step was $10 \mathrm{~m}$ at a distance of $294 \mathrm{~m}$ from the right edge of the model on the right-hand boundary of the B906 working face. This is approximately equal to the daily footage and 
32 excavations. Considering the recovery rate of top-coal caving mining, the mining height of the numerical tests was $10 \mathrm{~m}$. To simulate the collapse of the rock layer caused by underground mining, weak layers were added to different rock strata. A schematic of the numerical simulation model indicating the arrangement of the displacement monitoring points is shown in Fig. 2.

\subsection{UDEC model and simulation}

The UDEC numerical simulation model was simplified based on the stratigraphic occurrence of the P1 profile. The No.9 coal mined area in the P1 profile was $150 \mathrm{~m}$ from the left-hand boundary of the model and $185 \mathrm{~m}$ from the right-hand boundary of the model. To deeply examine the movement and deformation of the slope rock mass during the advancing process of the underground mining face, the stress distribution characteristics of the two mining schemes under field conditions were compared and analyzed. The design scheme is shown in Fig. 3.

\section{Comparative analysis of deformation and destruction law of slope rock mass}

\subsection{Destruction and movement of rock mass}

Figure 4 and 5 respectively show the simulation results of rock mass failure of open-pit slope in inverse-slope mining and along-slope mining, and the corresponding displacement monitoring data are shown in Table 2.In the process of inverse-slope and along-slope mining, the $+1375 \mathrm{~m}$ step and its upper rock and soil mass are seriously damaged, and the rock and soil mass caves, topples, and falls, and it slips to the goaf. However, during inverse-slope mining, the degree of damage to the rock and soil mass in this area is relatively serious, and the amount of movement is also larger (Table 2).

During the inverse-slope mining, the weak layer of wind-oxidized coal produces a large amount of damage, and the rock and soil mass between the $+1320 \mathrm{~m}$ flat plate and the $+1360 \mathrm{~m}$ flat plate takes this as the shear outlet. Under the compression of the caving rock mass on the left-hand side, the rock and soil mass will produce displacement towards the facing surface, and there is a landslide trend along the weak layer (Fig. $4 \mathrm{~b}$ and Table 2). In the along-slope mining, the influence on the $+1375 \mathrm{~m}$ flat panel and its lower rock mass is not obvious, and the weak layer of wind-oxidized coal at the upper part of the No.4 coal seam only produces a small amount of damage near the slope surface. However, the disturbance of the soil at the back edge during the along-slope mining is more obvious than that during the inverse-slope mining.

As can be seen from the failure characteristics and displacement of the slope rock mass, the influence of underground mining on the slope of coordinated open-pit and underground mining is skewed. Relative to the slope in front of the advancing direction of the mining face, the side slope of the open-off cut in the mining face is more seriously disturbed by the mining.

\subsection{Stress distribution characteristics of rock mass}

Figures 6 and 7 show the horizontal stress contours of the slope rock mass in the process of alongslope and inverse-slope mining, respectively, of the No.9 coal seam at the location of the P1 section. As can be seen, the hinged structure of broken rock beams directly above the open-off cut side and directly above the coal wall position of the working face caused stress concentration on the slope rock mass at these two positions during the stoping process of the underground mining face. Compared with along-slope mining, the slope rock mass stress concentration under inverse-slope mining is more obvious. The fundamental reason for the horizontal dislocation of the upper plate of the slope is the stress concentration directly below the slope. It is obvious that inverse-slope mining has a greater influence on the deformation and failure of the slope. This conclusion is consistent with the results of the RFPA analysis.

It can be seen from the figures that, regardless of the mining direction, the degree of stress concentration in the rock mass on the side of the open-off cut side is more obvious than that in the upper rock mass of the underground mining face. This further verifies that underground mining disturbance has a more serious impact on the side slope of the open-off cut in the underground mining face. Therefore, under the same other conditions, the mining direction along the slope can reduce the influence range and degree of mining disturbance on the slope. 


\section{Experiments}

Using the principles similarity theory, this section studies the slope deformation and failure laws of the Antaibao open-pit mine under co-mining through experiments with similar materials. The tests considered along-slope and inverse-slope mining of the No.9 coal seam and compared the results with those from the numerical simulations to provide a basis for studying the slope deformation and failure mechanisms.

\subsection{Establishment of similarity model}

To make a model that is similar to the entity prototype, it is necessary to ensure that the corresponding parameters are in a certain proportional relationship and the mathematical and physical equations of each corresponding parameter are the same. Specifically, the model and the entity must be similar in the following three respects.

(1) Geometric similarity: the model is required to have similar solid geometry. For this reason, the length ratio must be constant, and a geometric similarity ratio of 1:200 was selected according to the actual conditions of the site and the needs of the test.

(2) Similar physical conditions: the model is required to be similar to all corresponding motion situations of the physical prototype; that is, the speed, acceleration, and motion time of each corresponding point are required to be in a certain proportion. Therefore, the time ratio must be constant, that is

$a_{t}=\frac{t_{\mathrm{P}}}{t_{\mathrm{M}}}=\sqrt{\alpha_{L}}=14.14$

where $t$ represents time, and the subscripts $\mathrm{P}$ and $\mathrm{M}$ represent the actual physical system and the similar model, respectively. There are two coal mining shifts and one inspection shift every day at the site, and the production time is $16 \mathrm{~h}$. The working hours for the model are therefore

$t_{\mathrm{M}}=\frac{16}{14.14}=1.13 \mathrm{~h}=68 \mathrm{~min}$.

The actual situation at the construction site is to advance $5 \mathrm{~m}$ every day, which equates to advancing by $1.5 \mathrm{~cm}$ every 30 min during the simulation.

(3) Similar forces: all forces of the model and the physical prototype are required to be similar. The bulk density ratio is required to be constant, that is

$a_{\gamma}=\frac{\gamma_{\mathrm{P}}}{\gamma_{\mathrm{M}}}$

where $\gamma$ is the bulk density. Under the action of gravity and internal stress, the dominant similarity criterion in the process of rock deformation and failure is

$\frac{\sigma_{\mathrm{M}}}{\gamma_{\mathrm{M}} L_{\mathrm{M}}}=\frac{\sigma_{\mathrm{P}}}{\gamma_{\mathrm{P}} L_{\mathrm{P}}}$

where $\sigma$ is the unidirectional compressive strength. The similarity constants $a_{\sigma}, a_{\gamma}$, and $a_{L}$ satisfy the relationship

$a_{\sigma}=a_{\gamma} a_{L}$

and we finally obtain

$\sigma_{\mathrm{M}}=\frac{\gamma_{\mathrm{M}}}{\gamma_{\mathrm{P}} \alpha_{L}} \sigma_{\mathrm{P}}=0.003 \sigma_{\mathrm{P}}$

The material parameters of the tests are shown in Table 1, and the ratios of similar materials are shown in Table 3.

\subsection{Along-slope mining}

An experiment was conducted to simulate subsidence failure of the overburden, along with the deformation and movement characteristics of the slope during along-slope mining of the No.9 coal 
seam B906 working face. It also explored the limit position of the mining working face in these conditions. A schematic is shown in Fig. 8, and the starting state of the system is shown in Fig. 9.

When the working face advanced to the design stop-line position $(500 \mathrm{~m})$, the integrity of the rock mass of each berm below the +1405 berm was maintained, and the rock mass above the coal wall of the working face tended to rotate in the direction of the goaf. However, due to the restraint of the "masonry beam structure," the upper berms of the slope (especially the +1375 berm and +1405 berm) moved horizontally toward the empty side, but the displacement was small (Fig. 10).

After continuing to advance to $545 \mathrm{~m}$, a new tension crack was formed at the bottom of the +1375 step. The upper rock mass once again formed three zones A1, B1, and $\mathrm{C} 1$, and the movement and failure of the rock mass in each zone was the same as before. The $+1405,+1390$, and +1375 berms belonged to zone $\mathrm{B} 1$, the +1360 berm belonged to zone $\mathrm{A} 1$, and the integral turning of zone $\mathrm{B} 1$ towards the goaf caused the flat pans in this zone to be far from the free face. The horizontal movements of the $+1360,+1375$, and +1390 berms were $0.4 \mathrm{~m}, 1.6 \mathrm{~m}$, and $1.4 \mathrm{~m}$, respectively. In summary, these results show that the working face can be advanced to $540 \mathrm{~m}$ in along-slope mining (Fig. 11). When the working face was advanced to $560 \mathrm{~m}$, the upper rock mass collapsed, the +1405 , +1390 , and +1375 berms were damaged, and the collapsed crack penetrated to the bottom of the +1375 step (Fig. 12).

\subsection{Inverse-slope mining}

An experiment was conducted to simulate subsidence failure of the overburden, along with the deformation and movement characteristics of the slope during inverse-slope mining of the No.9 coal seam B906 working face. Comparisons with the corresponding situation in along-slope mining were made, and the differences in the deformation and failure of the rock mass near the slope under the two conditions were comprehensively analyzed. A schematic of the system is shown in Fig. 13.

Figure 14 shows the working face advanced to $130 \mathrm{~m}$. When the working face was advanced further to $470 \mathrm{~m}$, the upper key layer of coal in the No.9 seam broke and the rock mass above the key layer collapsed. At this time, the rock mass behind the working face lost its support and fell as a whole, and the height $h$ was about $5 \mathrm{~m}$ (Fig. 15).

As the working face continued to advance, and the upper rock and soil continued to collapse. When the working face advanced to $560 \mathrm{~m}$, the +1440 berm was destroyed. At this time, the horizontal and vertical displacements of each berm on the slope reached their maximum values. The most serious damage caused by well mining subsidence was to the flat pan +1405 berm, and the main failure mode was settlement failure. The $+1390,+1375,+1360$, and +1345 berms outside the range of the collapse angle were subjected to a horizontal thrust $F$ generated by the rock-beam hinged structure, and all produced a horizontal displacement toward the free surface. The horizontal movement of other berms was below $0.4 \mathrm{~m}$. Because the rock mass and surrounding rock in the lower collapse zone did not form a hinged structure, the steps at the bottom of the slope basically did not move. The measurements show that the caving angle of the coal-wall position of the working face was about $56^{\circ}$, and the caving angle of the open-off cut position was about $63^{\circ}$ (Fig. 16).

These results show that, under along-slope mining conditions, the caving angle of the No.9 coal seam on the side of the open-off cut is $64^{\circ}$ and the coal-wall side caving angle of the working face is $55^{\circ}$. The corresponding values under inverse-slope mining conditions are $63^{\circ}$ and $56^{\circ}$, respectively. Regardless of the mining direction, the caving angle of the coal-wall side of the working face is smaller than that of the open-off cut side, and the difference between the two is about 7-9 ${ }^{\circ}$. Through comparative study of the failure processes of the overlying strata, it was found that this phenomenon is caused by the different failure mechanisms of the fixed beam and the cantilever beam above the goaf. The collapse angle on the side of the open-off cut is caused by the breakage of the fixed beam structure, and the collapse angle on the coal-wall side of the working face is caused by breakage of the cantilever beam structure.

In terms of the horizontal movement characteristics of each berm, the impact ranges of alongslope and inverse-slope mining on the slope are basically the same, but the degree of impact of the former is much smaller than that of the latter. Regarding vertical movement characteristics, the impact 
range of along-slope mining is slightly larger than that of inverse-slope mining, but the impact of the former is far less severe than that of the latter. These features are basically consistent with the previously described numerical simulation results. In summary, when the boundary parameters are the same, inverse-slope mining has a greater impact on the deformation and failure of each flat plate on the slope when compared with along-slope mining.

\section{Field application analysis}

Regarding the coal-wall and open-off cut side caving angles ( $\alpha$ and $\beta$, respectively) of alongslope mining and inverse-slope mining (indicated by subscripts 1 and 2 , respectively), the results of the numerical simulations and the similar-material experiments show that $\alpha_{1}<\beta_{1}, \alpha_{2}<\beta_{2}, \beta_{1} \approx$ $\beta_{2}$, and $\alpha_{1} \approx \alpha_{2}$, as shown in Fig. 17a.

It can be seen from Fig. 17a that under the condition of the same position of the open-off cut or stoppage line of the well mining face, the influence range of the inverse-slope mining on the upper slope is larger than that of the along-slope mining. Therefore, under the condition of ensuring the same damage range of the top of the slope, the slope mining can recover part of the coal pillar more, $\mathrm{L}$ is the difference between the limit position of the alongslope mining and the inverse-slope mining, as shown in Fig. 17b.Among them: $L=H\left(\operatorname{ctg} \alpha_{1}-\operatorname{ctg} \beta_{1}\right)$, where $L$ is the difference between the limit positions of along-slope mining and inverse-slope mining and $H$ is the burial depth of the coal seam.

Taking Antaibao open-pit mine and Jinggong No. 2 mine as an example, the buried depth of the B906 fully mechanized coal caving face is about $150 \mathrm{~m}$, the side caving angle of the open-off cut is $64^{\circ}$, the side caving angle of the coal wall of the working face is $55^{\circ}$, and the calculation results show that $L$ is about $31.9 \mathrm{~m}$. Therefore, compared with inverse-slope mining, the increased length of coal pillar that can be recovered from along-slope mining is about $31.9 \mathrm{~m}$. According to the actual situation of the site, the average mining thickness of the coal seam is about $12.8 \mathrm{~m}$, the width of the working face is $300 \mathrm{~m}$, the coal bulk density is $1.5 \mathrm{t} \cdot \mathrm{m}^{-1}$, and the recovery rate is $85 \%$. This means that the extra coal that could be produced by along-slope mining is about $156000 \mathrm{t}$, bringing significant economic and social benefits.

It can be seen that in actual production using coordinated open-pit and underground mining, the recovery rate of coal resources can be improved by using along-slope mining. This has distinct practical value for engineering and is significant for the selection of the underground mining direction in coordinated open-pit and underground mining in similar conditions.

\section{Concluding remarks}

For a given set of mining conditions in coordinated open-pit and underground mining, the slope disturbances produced by underground inverse-slope mining are more obvious than those produced by along-slope mining. The influence of underground mining on the open pit mining slope is skewed; the slope rock mass on the open-off cut side is disturbed more than that on the coal-wall side. Compared with the slope in front of the advancing direction of the underground mining face, the degree of rock-mass damage and stress concentration of the slope of the open-off cut side are more serious. This verifies that the rock mass of the open-off cut side is more seriously disturbed by underground mining.

Under the condition of ensuring the same scope and degree of slope damage, compared with inverse-slope mining, the limit distance between the mining face and the facing face of the slope is small during along-slope mining, meaning more coal resources can be recovered. As such, in coordinated open-pit and underground mining practice, an along-slope mining direction is recommended to reduce adverse effects on slope stability and improve the recovery rate of coal resources.

\section{References}

Lan H, Li FM, Yao JG (2007) Research on surface subsidence of dump slope induced by mining in open colliery. Journal of China University of Mining and Technology 36(4):482-486

Liu XQ (2008) Optimization of surface-underground mining parameters and working length at Antaibao mine. Beijing: University of Science and Technology Beijing pp 47-58 
Liu XQ, Zhu JM, Feng JY, et al. (2008) Mechanism of the slope failure of horizontal thick coal seam under the condition of combined mining. Journal of China Coal Society 33(12):1346-1350

Liu XQ, Zhu JM, Lu Y (2007) Mining order and its optimization analysis under combined model of open-pit with underground mining. Chinese Mining Magazine 16(10):63-65

Sun SG (1999) Study of deformation and stability of rock slope under combined mining. Chinese Journal of Rock Mechanics and Engineering 18(2):239-239

Sun SG, Cai MF (2000) Study of sliding mechanism for slope due to the excavation from open pit into underground mine. Chinese Journal of Rock Mechanics and Engineering 19(1):126-129

Zhou J, Li SC, Ma PL (2012) Mechanism of the slope failure under the condition of combined mining based on RFPA. Coal Mining 17(2):106-108

Zhu JM, Feng JY, Peng XP, et al. (2010) The failure law of mine slope and the optimization of boundary parameter between open-pit and underground combined mining. Journal of China Coal Society 35(7):1089-1094

Zhu JM, Liu BK, Xu JH, et al. (2009) Open-pit and under-ground combined mining technology. Xuzhou: China University of Mining and Technology Press

Zhu JM, Liu XQ, Wu JP, et al. (2009) Similarity simulation on slope stability under condition of combined open and under-ground mining. Journal of Engineering Geology 17(2):207 


\section{Figures}

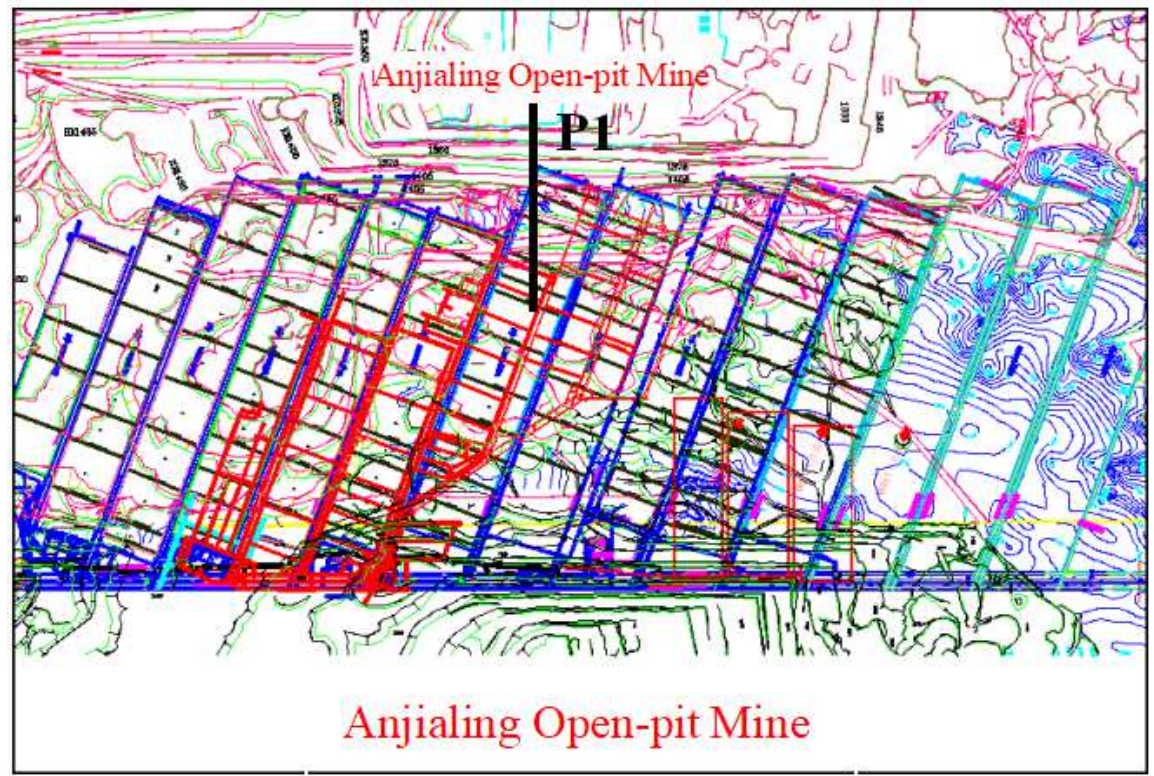

Fig. 1 Plan of coordinated open-pit and underground mining at Anjialing

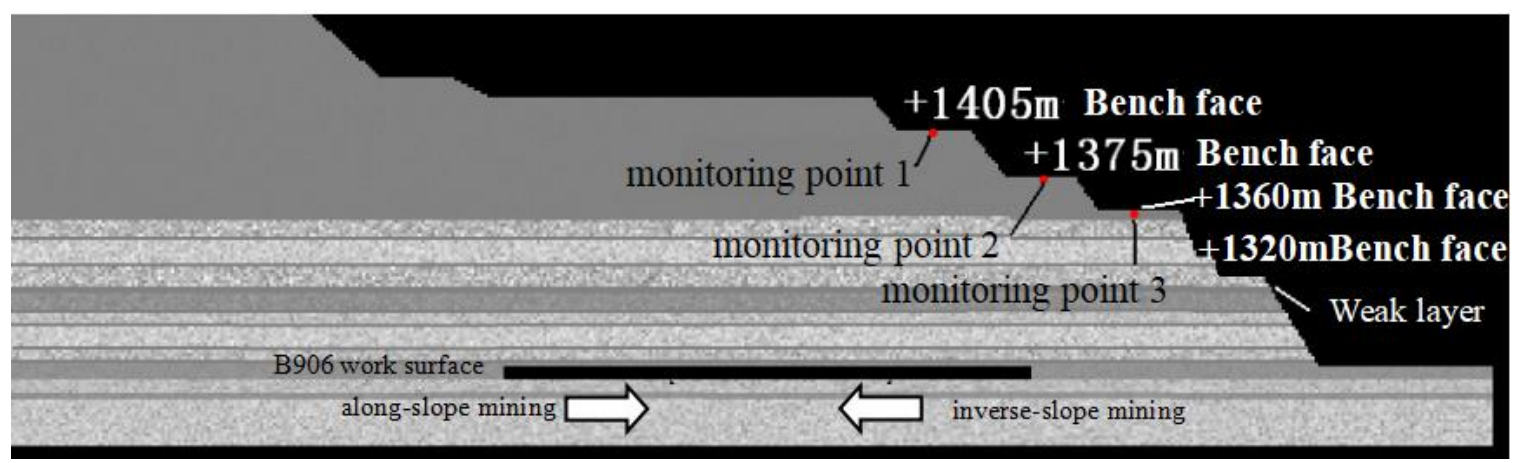

Fig. 2 RFPA numerical simulation model

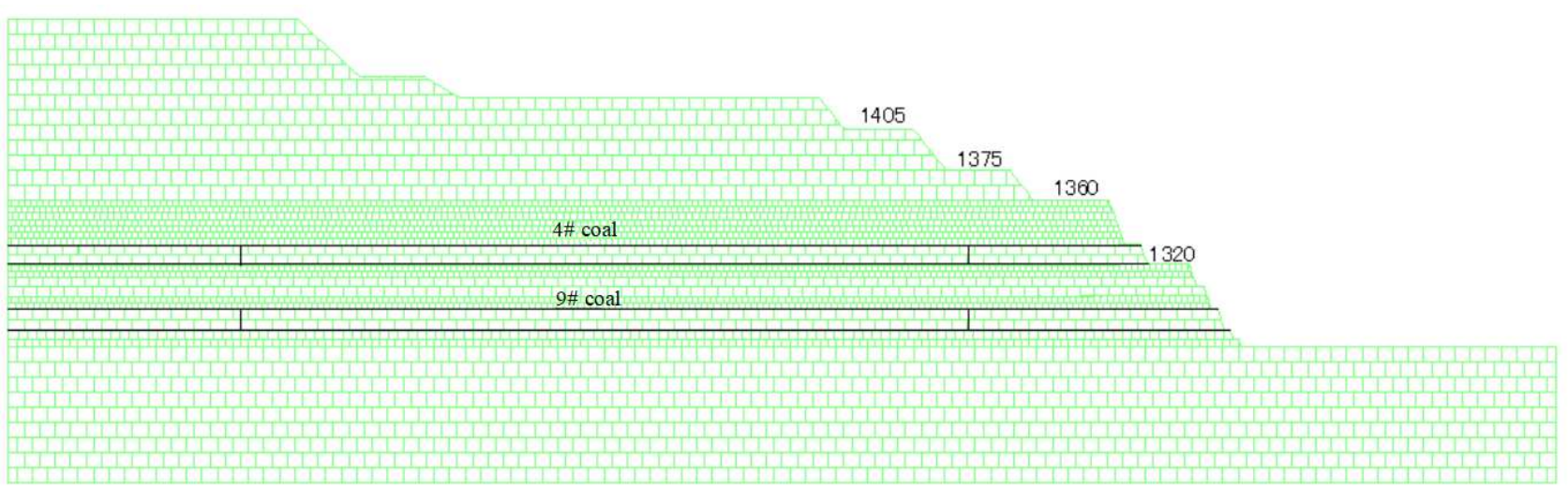

Fig. 3 UDEC numerical simulation model 


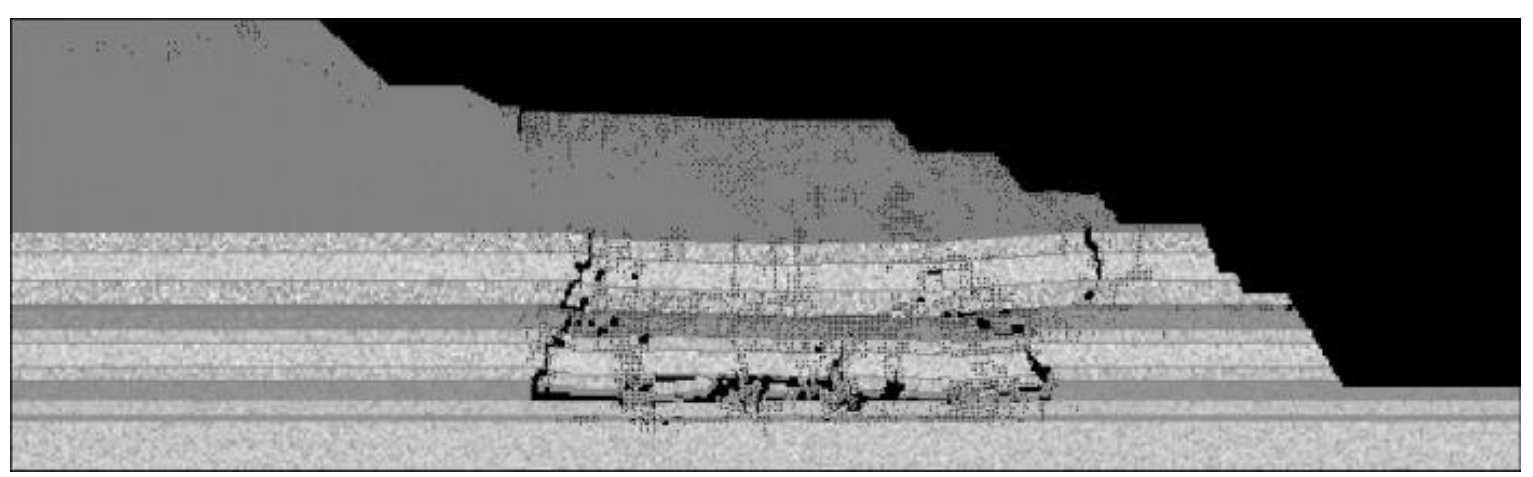

(a)

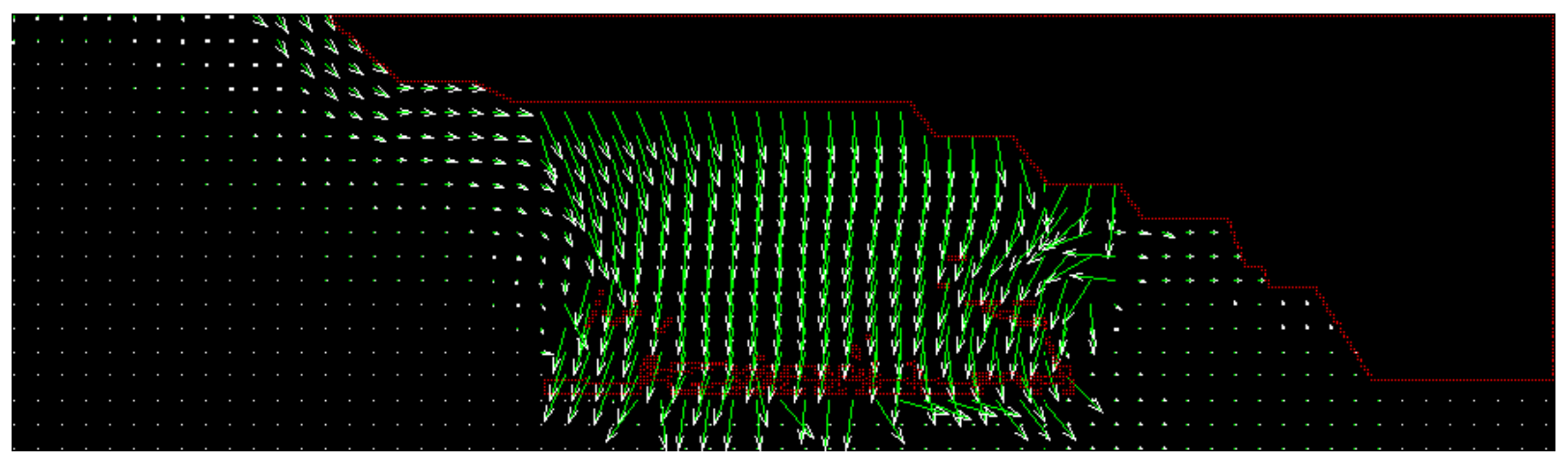

(b)

Fig. 4 Characteristic of slope deformation and failure under inverse-slope mining: (a) rock mass collapse diagram; (b) displacement vector diagram

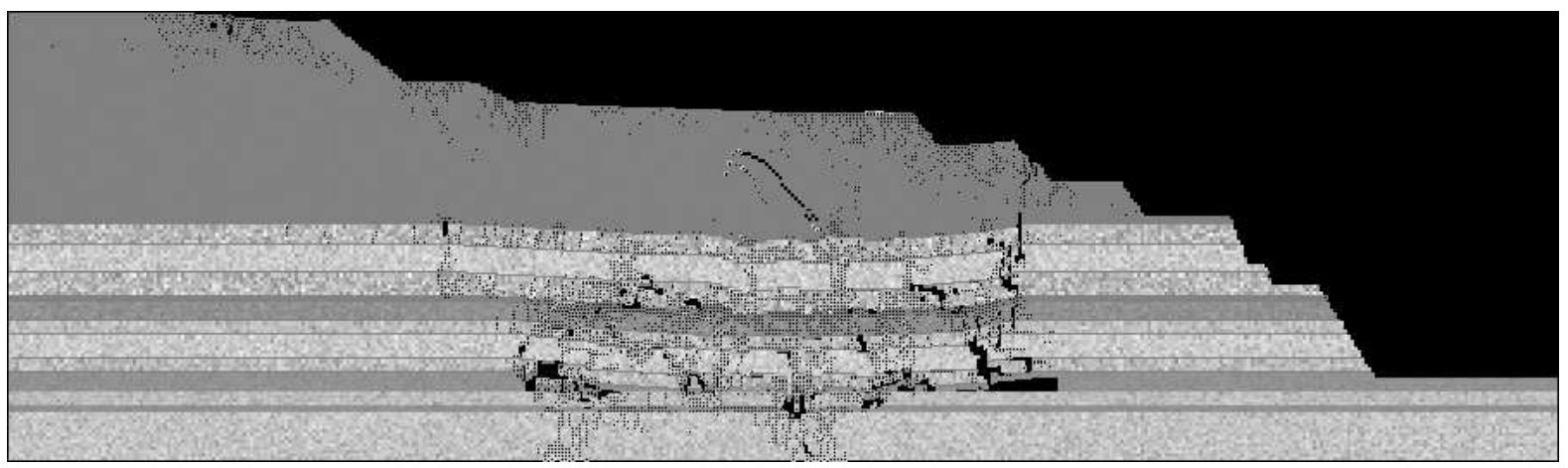

(a)

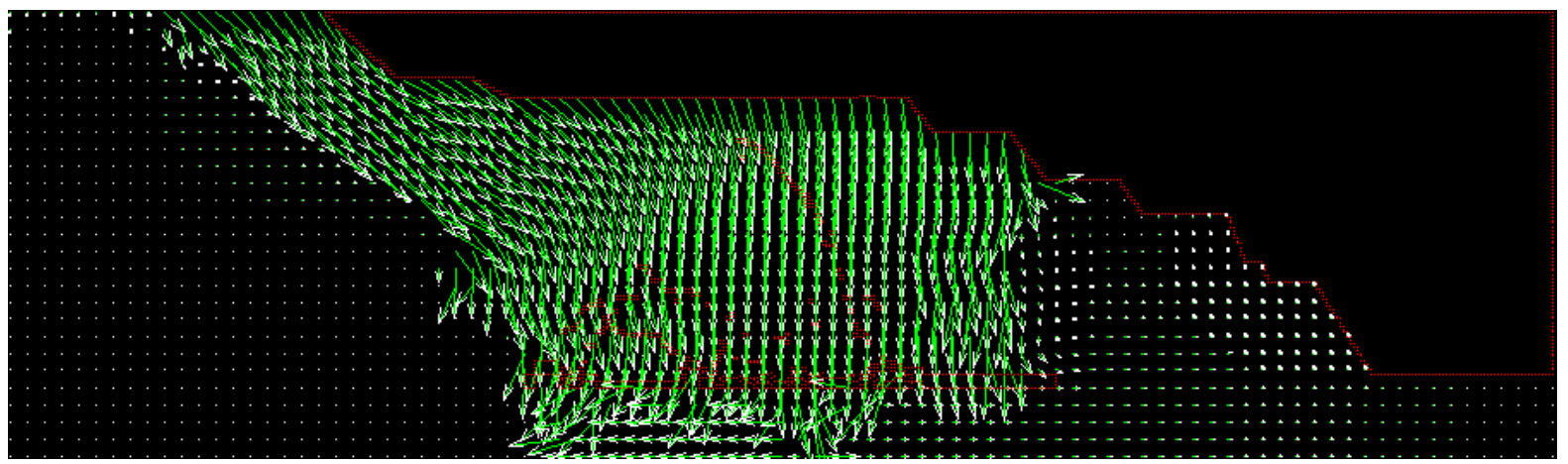

(b)

Fig. 5 Characteristic of slope deformation and failure under along-slope mining: (a) rock mass collapse diagram; (b) displacement vector diagram 


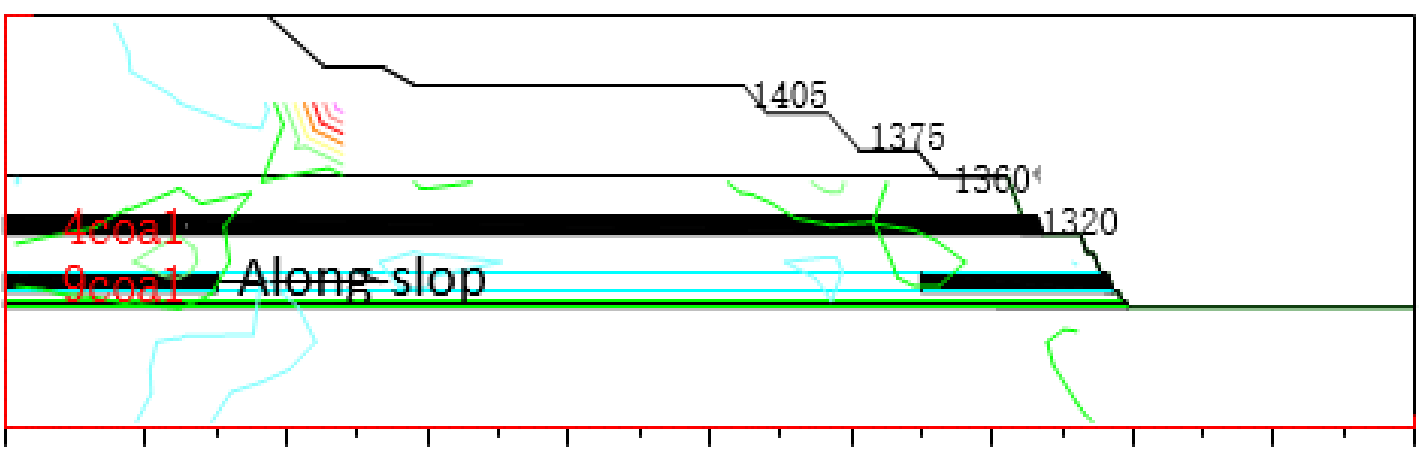

Fig. 6 Stress contours of slope rock mass under along-slope mining

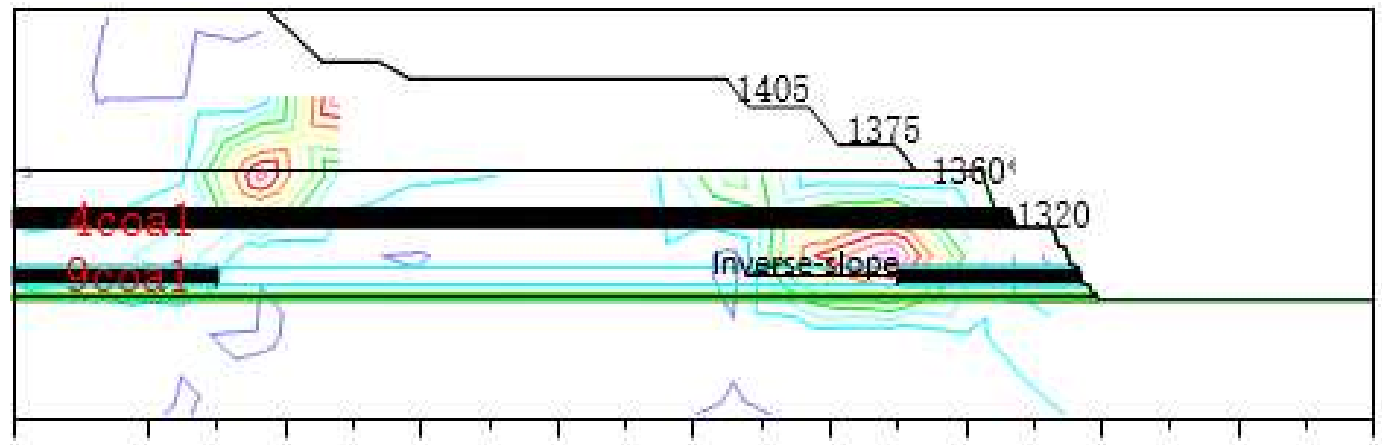

Fig. 7 Stress contours of slope rock mass under inverse-slope mining

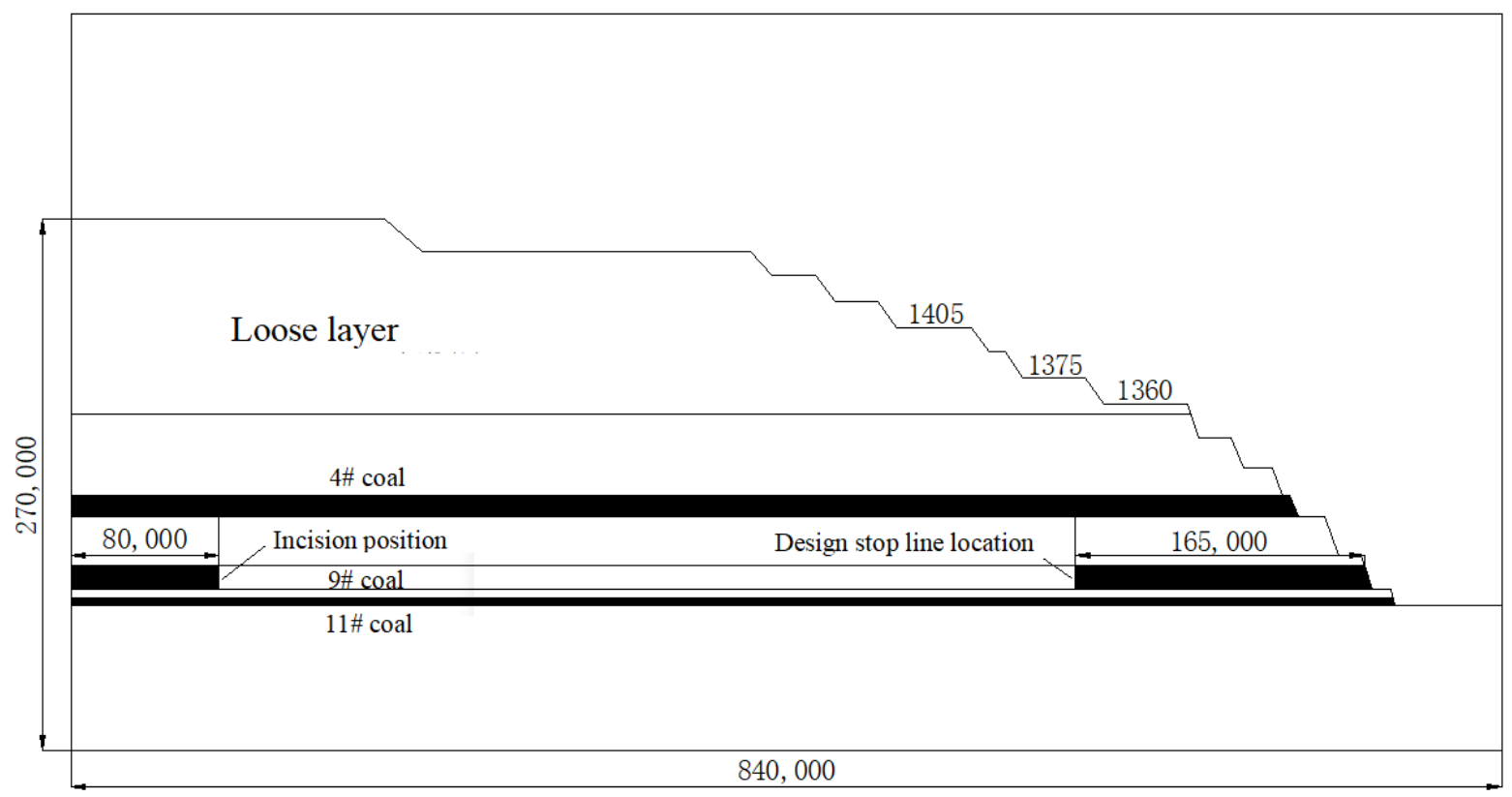

Fig. 8 Schematic diagram of similar-material physical model for along-slope mining of No.9 coal seam 


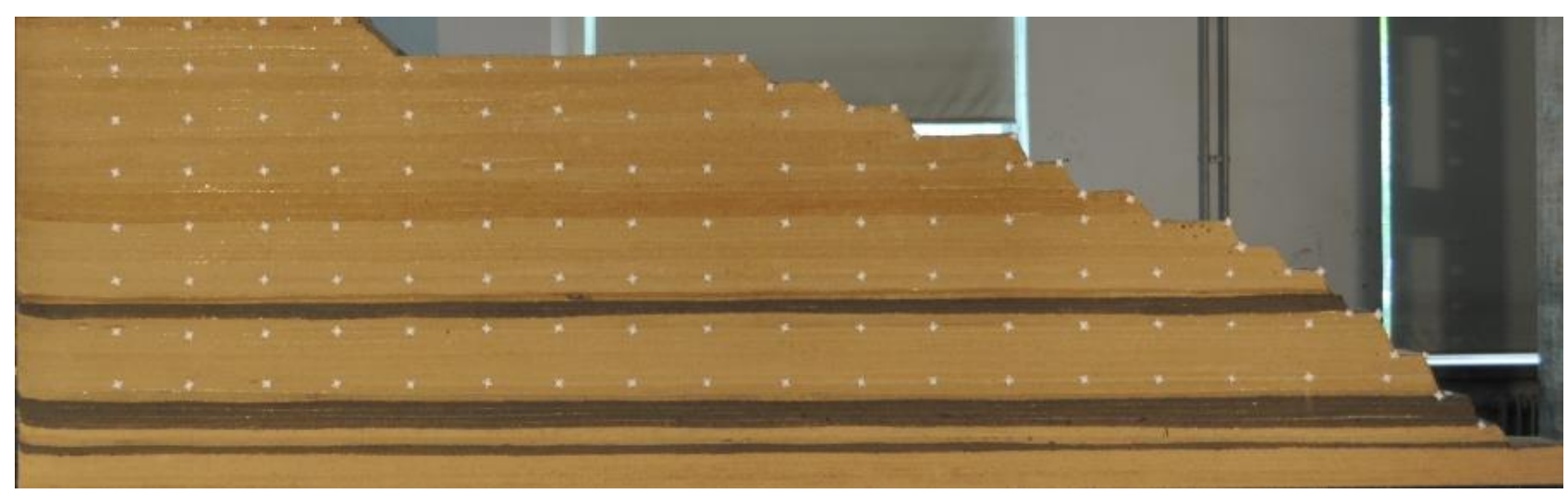

Fig. 9 Physical model before underground mining

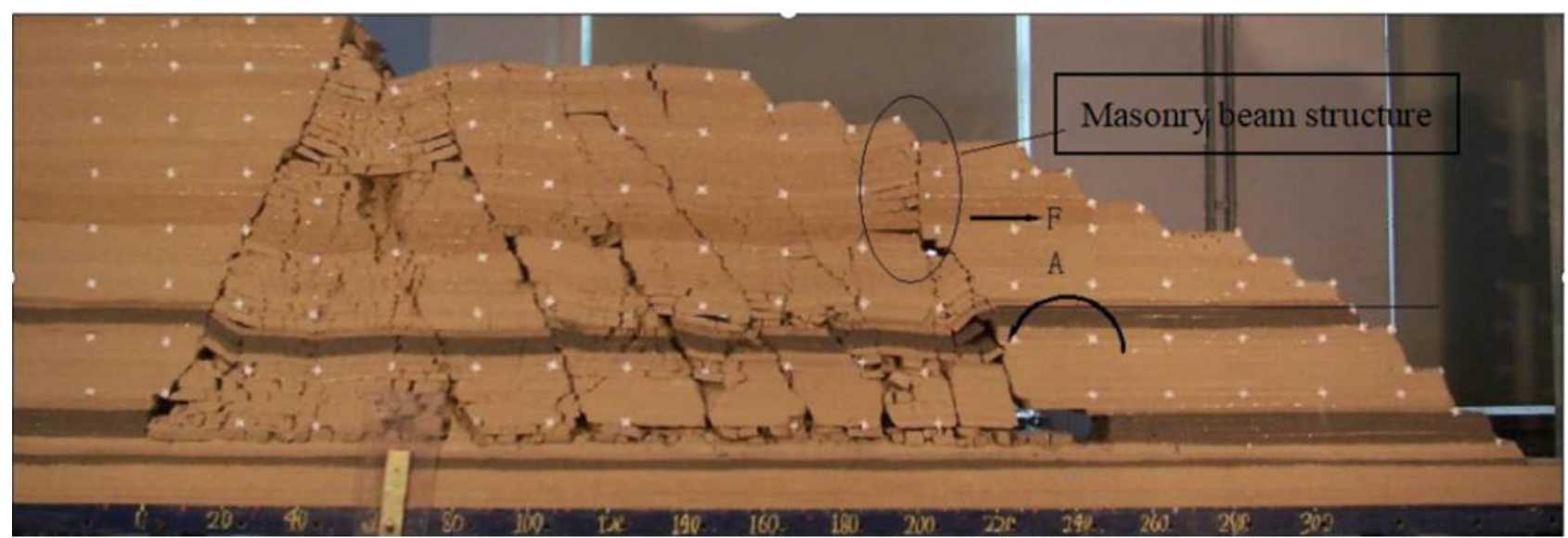

Fig. 10 Physical model after along-slope mining to $500 \mathrm{~m}$

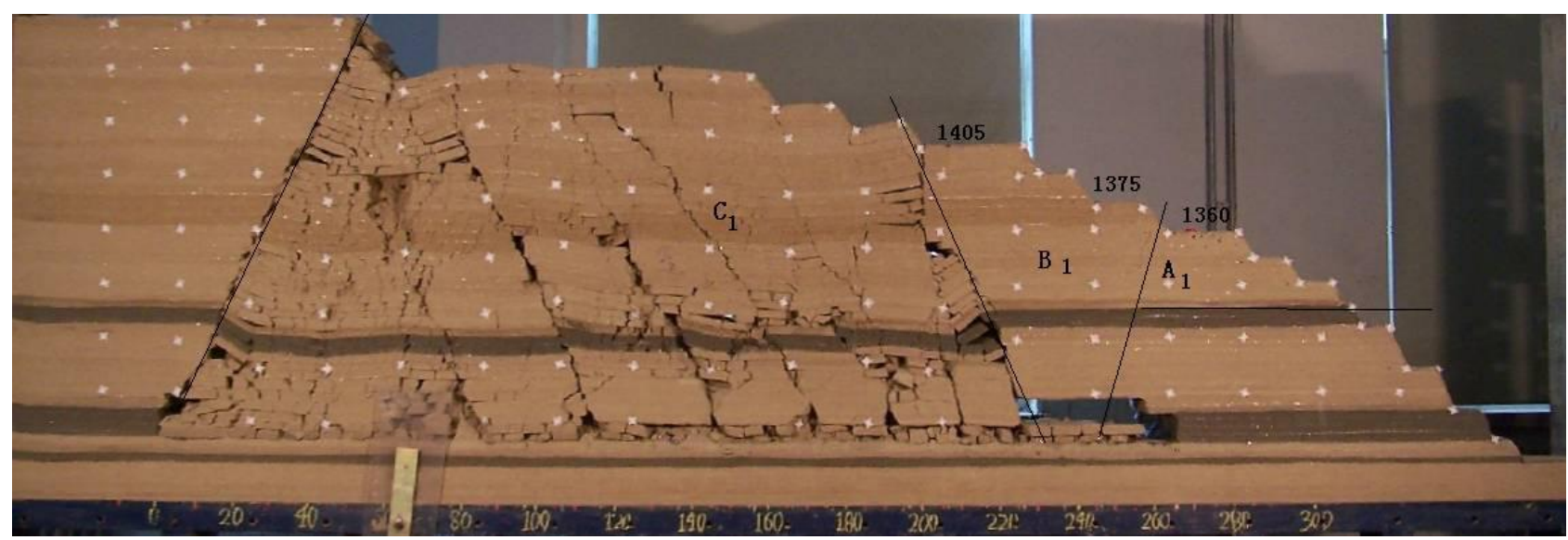

Fig. 11 Physical model after along-slope mining to $545 \mathrm{~m}$ 


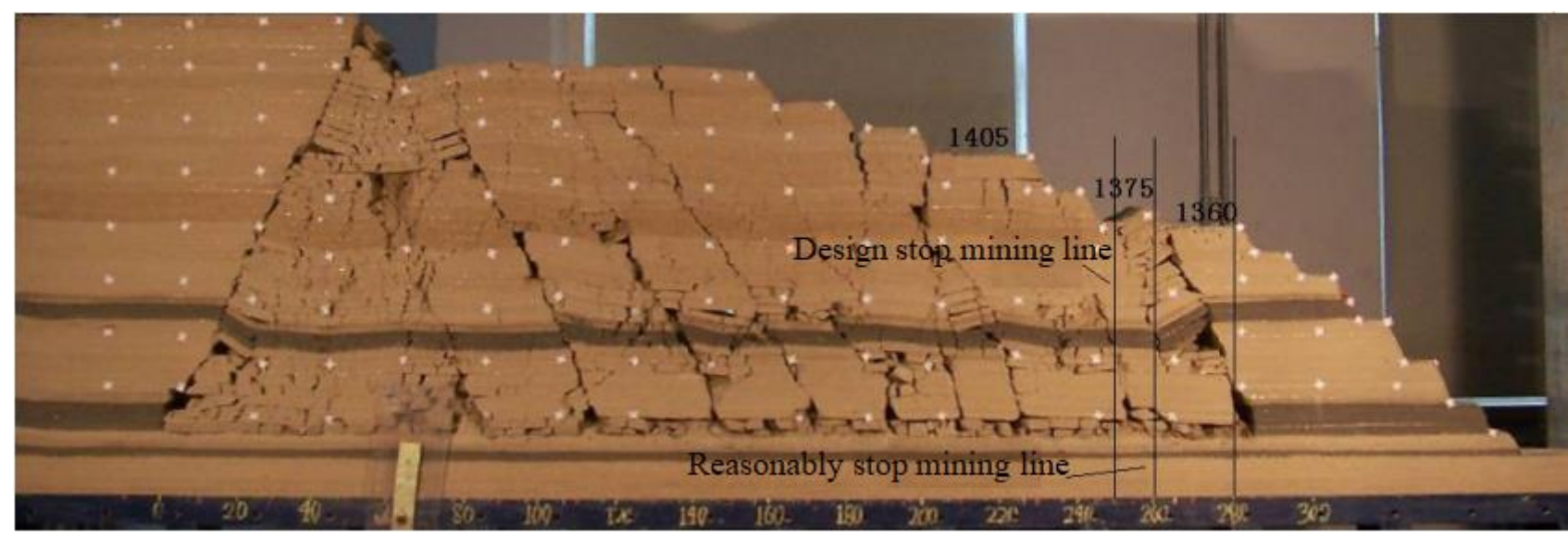

Fig. 12 Physical model after along-slope mining to $560 \mathrm{~m}$

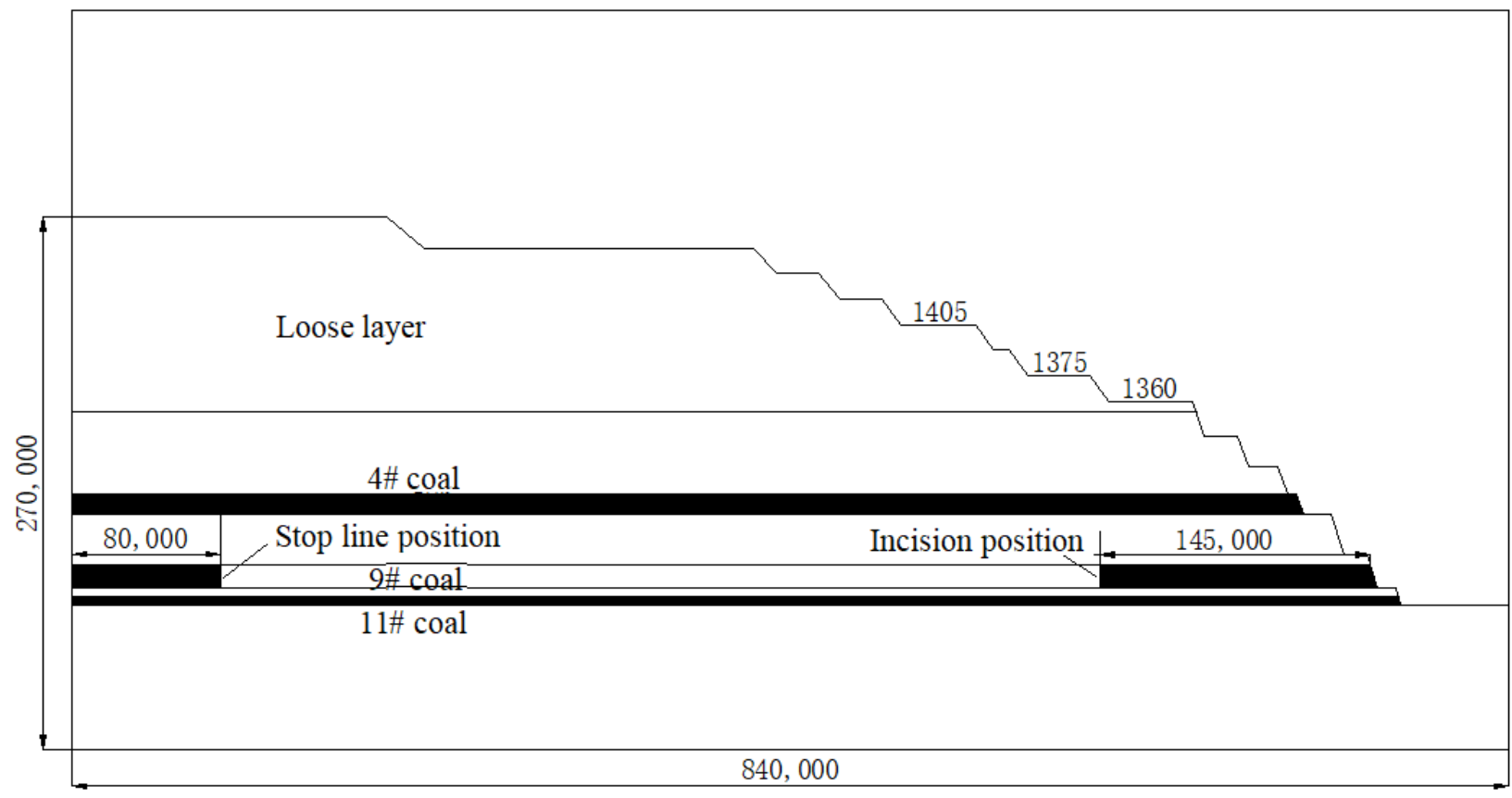

Fig. 13 Schematic diagram of similar-material physical model for inverse-slope mining of No.9 coal seam

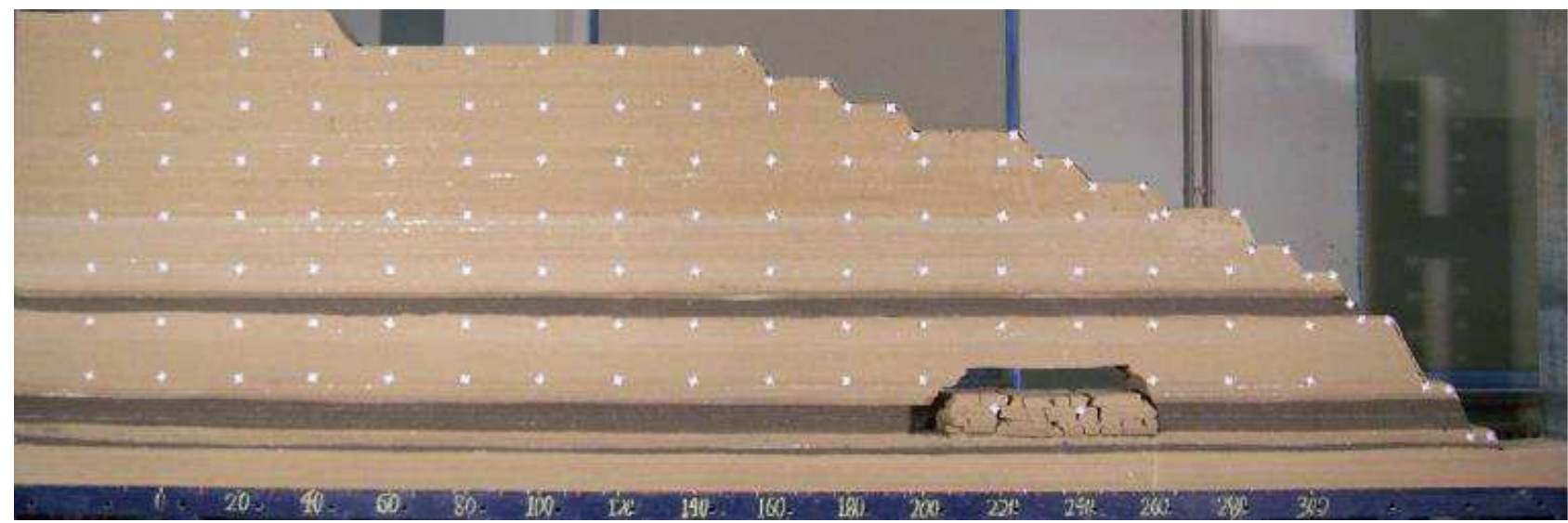

Fig. 14 Physical model after inverse-slope mining to $130 \mathrm{~m}$ 


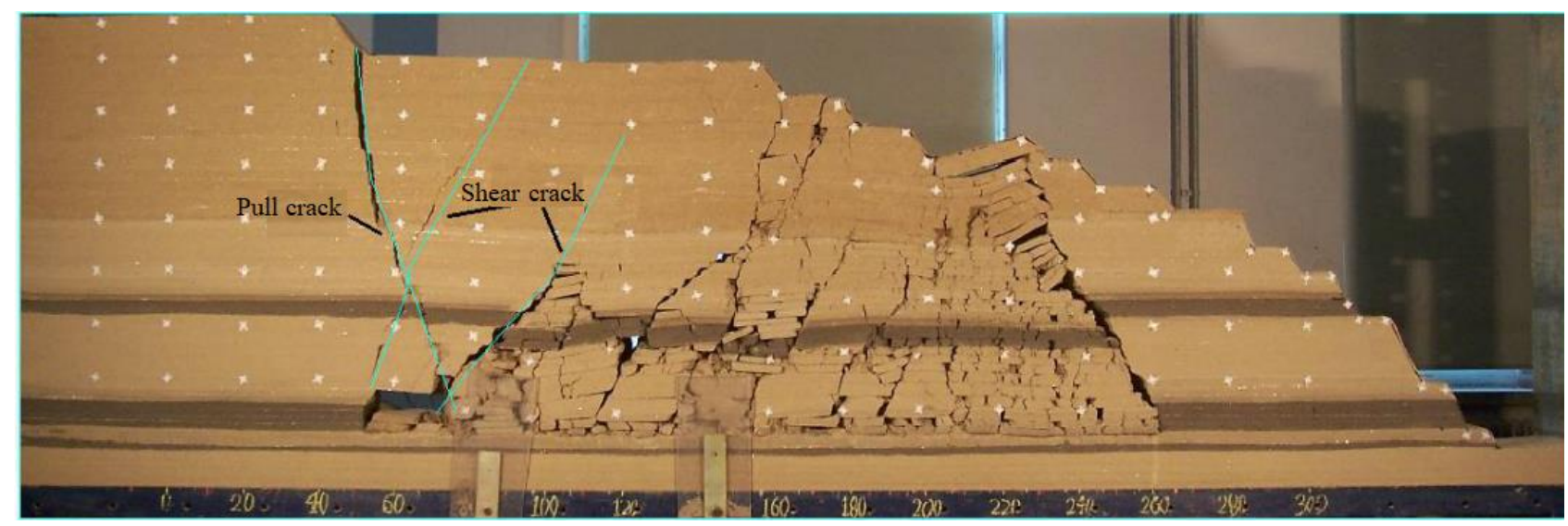

Fig. 15 Physical model after inverse-slope mining to $470 \mathrm{~m}$

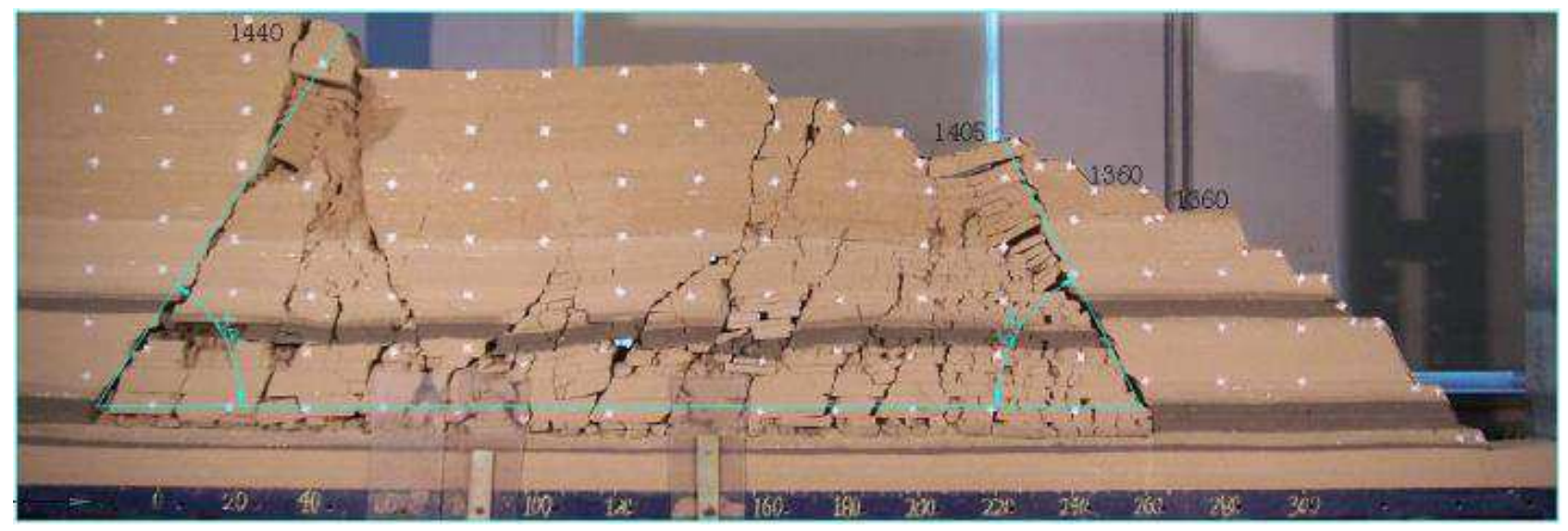

Fig. 16 Physical model after inverse-slope mining to $560 \mathrm{~m}$

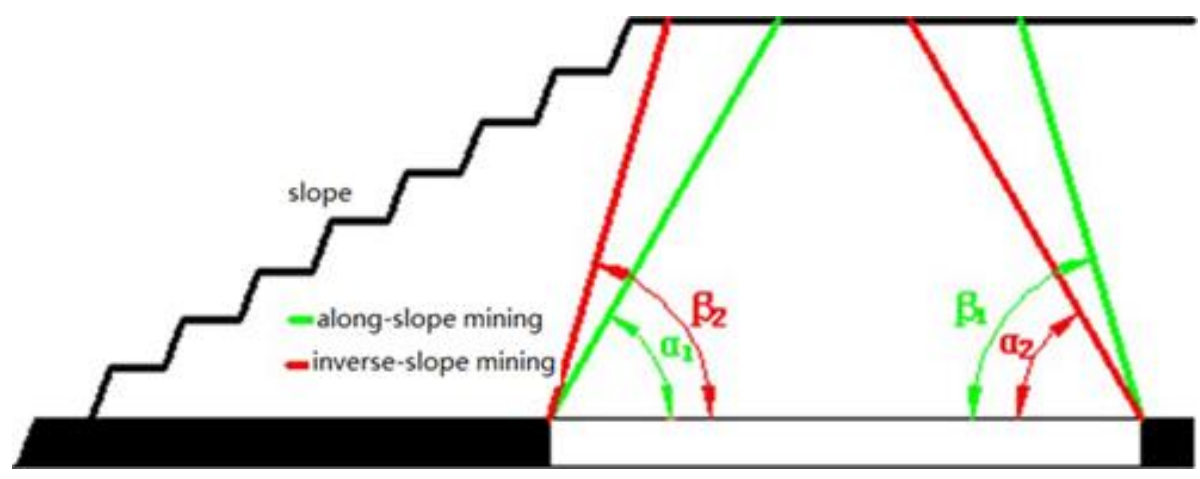

(a)

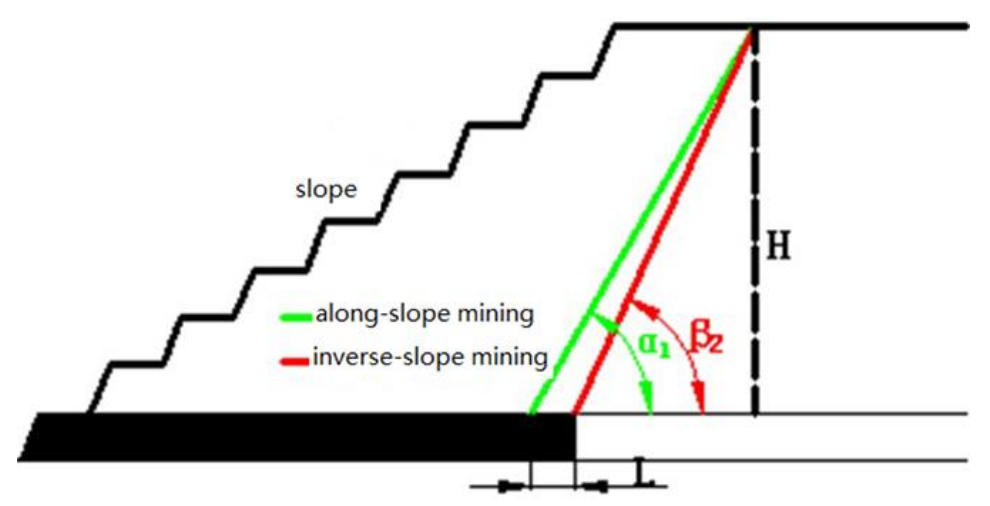

(b)

Fig. 17 Influence on boundary parameters of different mining directions 
Tables

Table 1 Physical and mechanical properties of rock and soil

\begin{tabular}{ccccccc}
\hline Stratum & $\begin{array}{c}\text { Elastic modulus } \\
(\mathrm{MPa})\end{array}$ & Poisson's ratio & $\begin{array}{c}\text { Density } \\
\left(\mathrm{kg} \cdot \mathrm{m}^{-3}\right)\end{array}$ & $\begin{array}{c}\text { Compressive } \\
\text { strength } \\
(\mathrm{MPa})\end{array}$ & $\begin{array}{c}\varphi \\
\left(^{\circ}\right)\end{array}$ & $\begin{array}{c}P \\
(\mathrm{MPa})\end{array}$ \\
\hline Topsoil & 15 & 0.42 & 1960 & 1 & 18 & 0.013 \\
Sandstone & 4200 & 0.32 & 2380 & 34 & 39 & 0.300 \\
Mudstone & 2800 & 0.34 & 2490 & 30 & 38 & 0.200 \\
Sandstone & 5500 & 0.30 & 2380 & 50.7 & 40 & 0.400 \\
Siltstone & 4600 & 0.32 & 2320 & 45 & 36 & 0.350 \\
Weak layer & 1000 & 0.40 & 2000 & 10 & 19 & 0.100 \\
No.4 coal & 1000 & 0.38 & 1440 & 21.7 & 36 & 0.295 \\
Shale & 2400 & 0.33 & 2450 & 40.5 & 42 & 0.300 \\
Siltstone & 4800 & 0.32 & 2600 & 39.4 & 38 & 0.500 \\
Shale & 3000 & 0.35 & 2580 & 45 & 38 & 0.500 \\
No.9 coal & 1200 & 0.36 & 1330 & 20.5 & 39 & 0.295 \\
Sandstone & 6900 & 0.28 & 2380 & 73.5 & 41 & 0.500 \\
No.11 coal & 1400 & 0.35 & 1400 & 19.5 & 36 & 0.295 \\
Sandstone & 2600 & 0.25 & 2600 & 66.6 & 44 & 0.500 \\
\hline
\end{tabular}

Table 2 Displacement monitoring data

\begin{tabular}{|c|c|c|c|c|c|c|}
\hline \multirow{2}{*}{$\begin{array}{l}\text { Mining } \\
\text { direction }\end{array}$} & \multicolumn{2}{|c|}{$\begin{array}{l}\text { Monitoring point } 1 \\
\quad(+1405 \mathrm{~m} \text { flat })\end{array}$} & \multicolumn{2}{|c|}{$\begin{array}{l}\text { Monitoring point } 2 \\
\quad(+1375 \mathrm{~m} \text { flat })\end{array}$} & \multicolumn{2}{|c|}{$\begin{array}{l}\text { Monitoring point } 3 \\
\quad(+1360 \mathrm{~m} \text { flat })\end{array}$} \\
\hline & $\begin{array}{c}\text { Horizontal } \\
\text { displacement }\end{array}$ & $\begin{array}{c}\text { Vertical } \\
\text { displacement }\end{array}$ & $\begin{array}{c}\text { Horizontal } \\
\text { displacement }\end{array}$ & $\begin{array}{c}\text { Vertical } \\
\text { displacement }\end{array}$ & $\begin{array}{c}\text { Horizontal } \\
\text { displacement }\end{array}$ & $\begin{array}{c}\text { Vertical } \\
\text { displacement }\end{array}$ \\
\hline $\begin{array}{l}\text { Inverse } \\
\text { slope }\end{array}$ & $-0.59 \mathrm{~m}$ & $7.19 \mathrm{~m}$ & $-1.09 \mathrm{~m}$ & $1.97 \mathrm{~m}$ & $0.16 \mathrm{~m}$ & $0.02 \mathrm{~m}$ \\
\hline $\begin{array}{l}\text { Along } \\
\text { slope }\end{array}$ & $-0.31 \mathrm{~m}$ & $5.54 \mathrm{~m}$ & $0 \mathrm{~m}$ & $0 \mathrm{~m}$ & $0 \mathrm{~m}$ & $0 \mathrm{~m}$ \\
\hline
\end{tabular}

Note: horizontal displacement is positive towards the facing surface and vertical displacement is positive downwards.

Table 3 Material ratio

\begin{tabular}{ccccccccc}
\hline $\begin{array}{c}\text { Layer } \\
\text { number }\end{array}$ & Lithology & $\begin{array}{c}\text { Thickness } \\
(\mathrm{cm})\end{array}$ & $\begin{array}{c}\text { Density } \\
\left(\mathrm{g} \cdot \mathrm{cm}^{-3}\right)\end{array}$ & $\begin{array}{c}\text { Compressive } \\
\text { strength(MPa) }\end{array}$ & $\begin{array}{c}\text { Proportion } \\
\text { number }\end{array}$ & $\begin{array}{c}\text { Bone-glue } \\
\text { ratio }\end{array}$ & $\begin{array}{c}\text { Ash-paste } \\
\text { ratio }\end{array}$ \\
\hline 13 & Topsoil & 55 & 1.95 & 1.8 & 0.005 & $13: 1: 0$ & $13: 1$ & $1: 0$ \\
12 & Sandstone & 6.5 & 2.30 & 56 & 0.168 & $8: 7: 3$ & $8: 1$ & $7: 3$ \\
11 & Mudstone & 8 & 2.39 & 25.12 & 0.075 & $9: 7: 3$ & $9: 1$ & $7: 3$ \\
10 & Sandstone & 6 & 2.37 & 79.16 & 0.237 & $7: 5: 5$ & $7: 1$ & $5: 5$ \\
9 & Weak layer & 2 & 1.46 & 20 & 0.060 & $10: 1: 0$ & $10: 1$ & $1: 0$ \\
8 & No.4 coal & 5 & 1.44 & 14.3 & 0.043 & $9: 8: 2$ & $9: 1$ & $8: 2$ \\
7 & Gangue & 4.5 & 2.58 & 62.84 & 0.189 & $8: 6: 4$ & $8: 1$ & $6: 4$ \\
6 & Key layer & 7 & 2.65 & 92.34 & 0.277 & $6: 6: 4$ & $6: 1$ & $6: 4$ \\
5 & Gangue & 3.5 & 2.58 & 62.84 & 0.189 & $8: 6: 4$ & $8: 1$ & $6: 4$ \\
4 & No.9 coal & 7 & 1.49 & 16.32 & 0.049 & $9: 8: 2$ & $9: 1$ & $8: 2$ \\
3 & Sandstone & 3 & 2.37 & 79.16 & 0.237 & $7: 5: 5$ & $7: 1$ & $5: 5$ \\
2 & No.11 coal & 2 & 1.49 & 16.32 & 0.049 & $9: 8: 2$ & $9: 1$ & $8: 2$ \\
\hline
\end{tabular}

Note: water weight $=$ total weight $\times 7 \%$ 
Figures

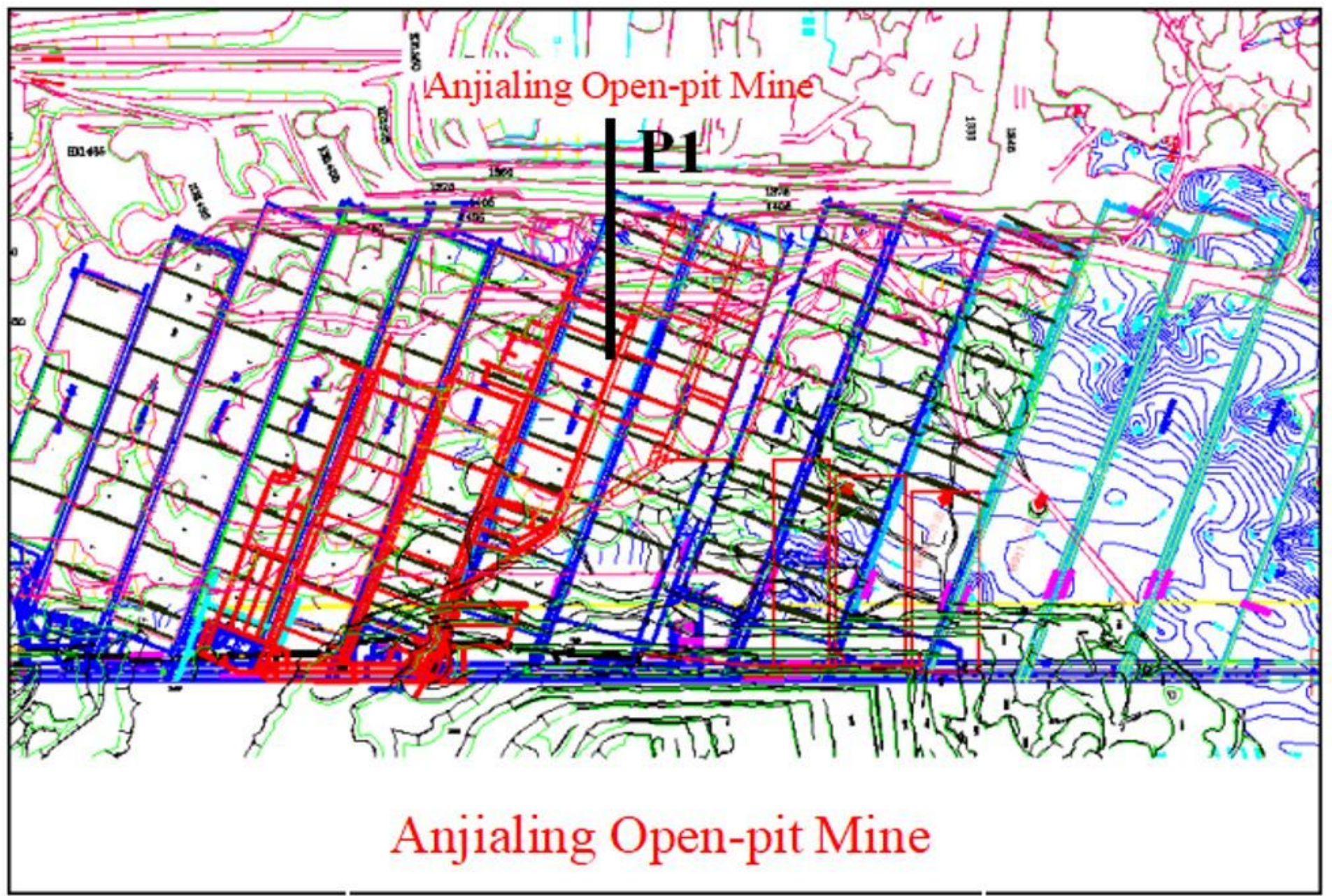

Figure 1

Plan of coordinated open-pit and underground mining at Anjialing

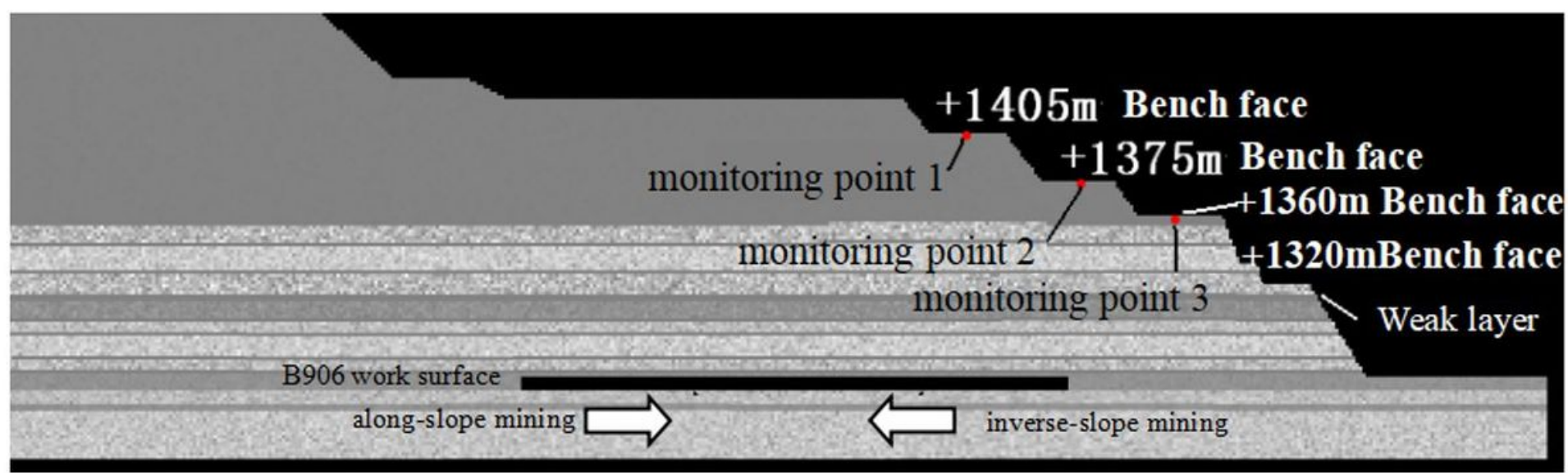

Figure 2 


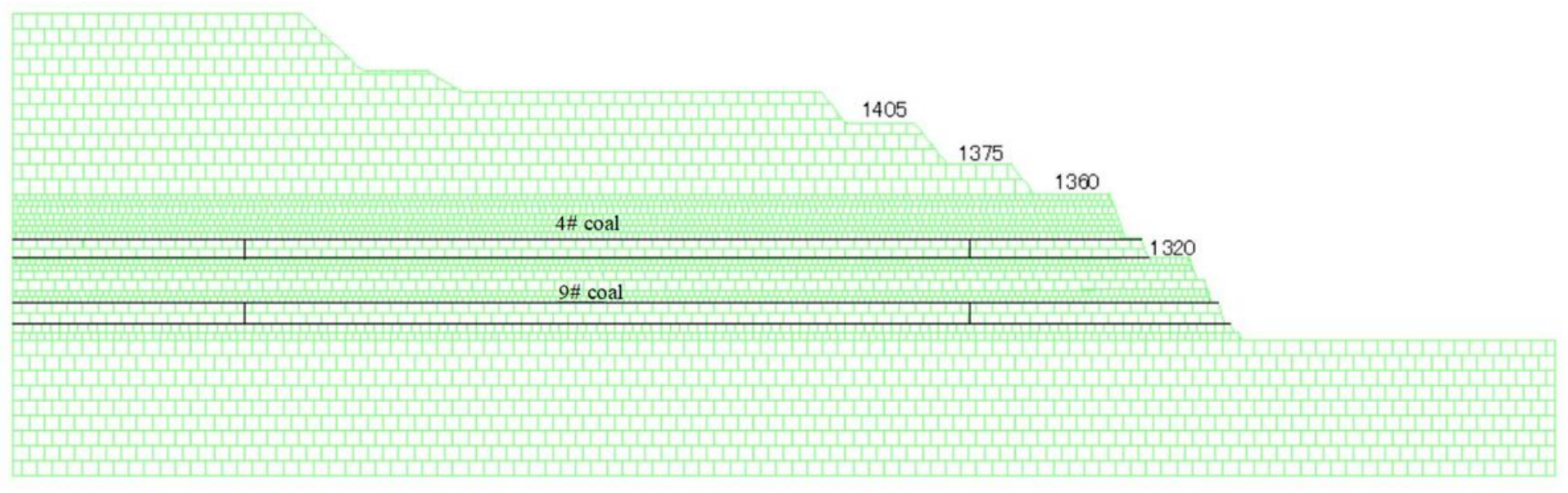

\section{Figure 3}

UDEC numerical simulation model

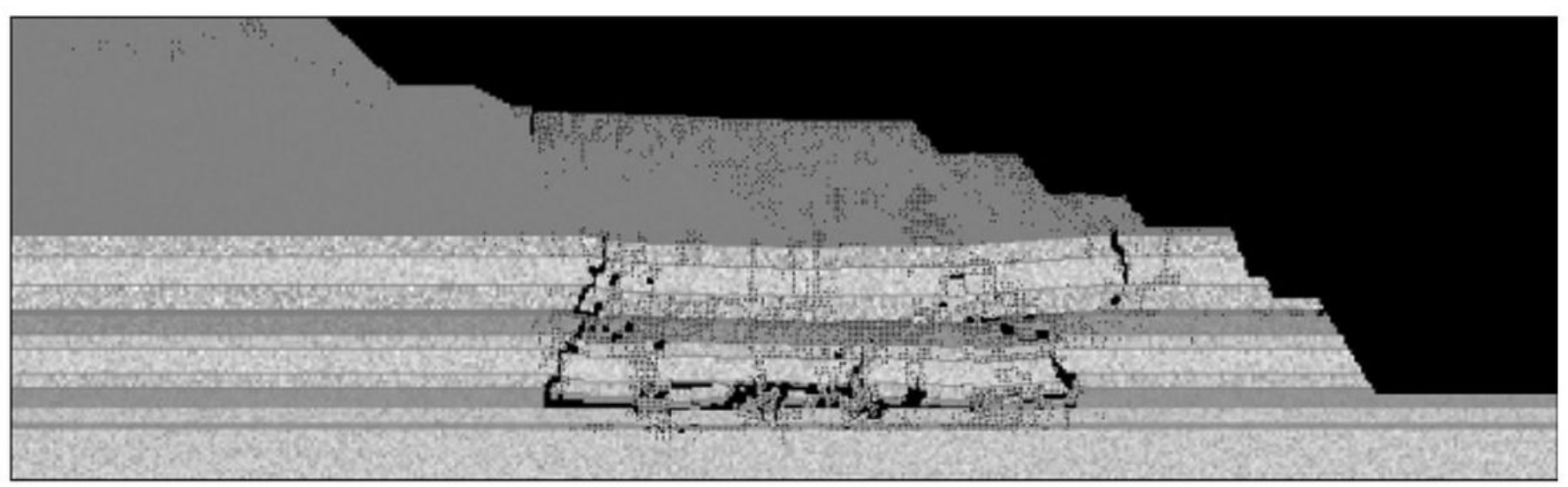

(a)

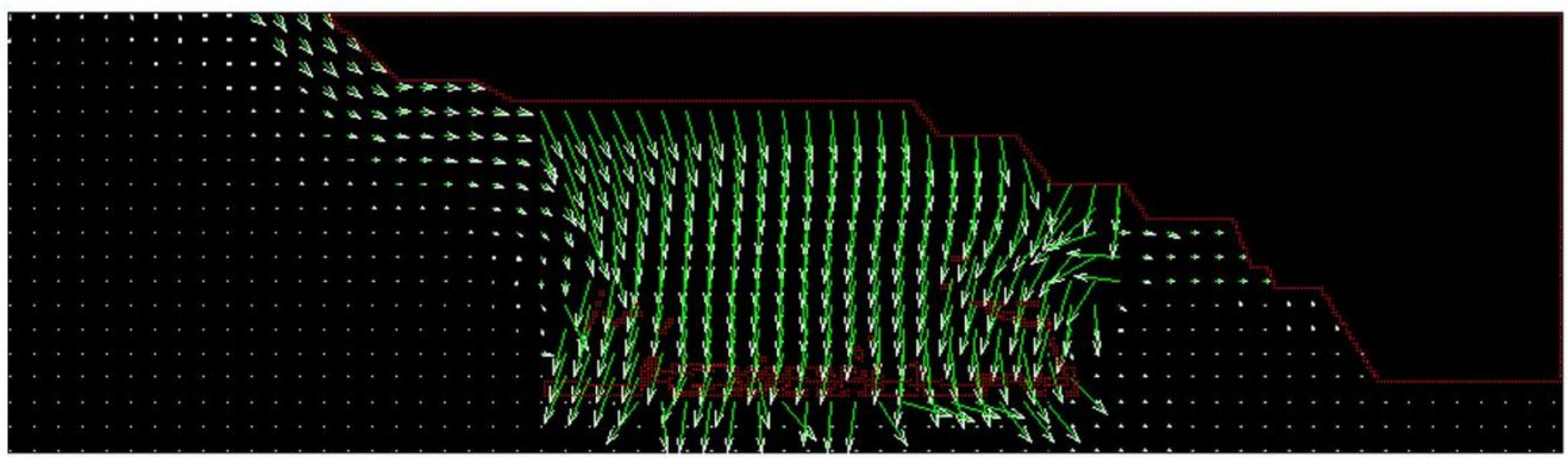

(b)

Figure 4

Characteristic of slope deformation and failure under inverse-slope mining: (a) rock mass collapse diagram; (b) displacement vector diagram 


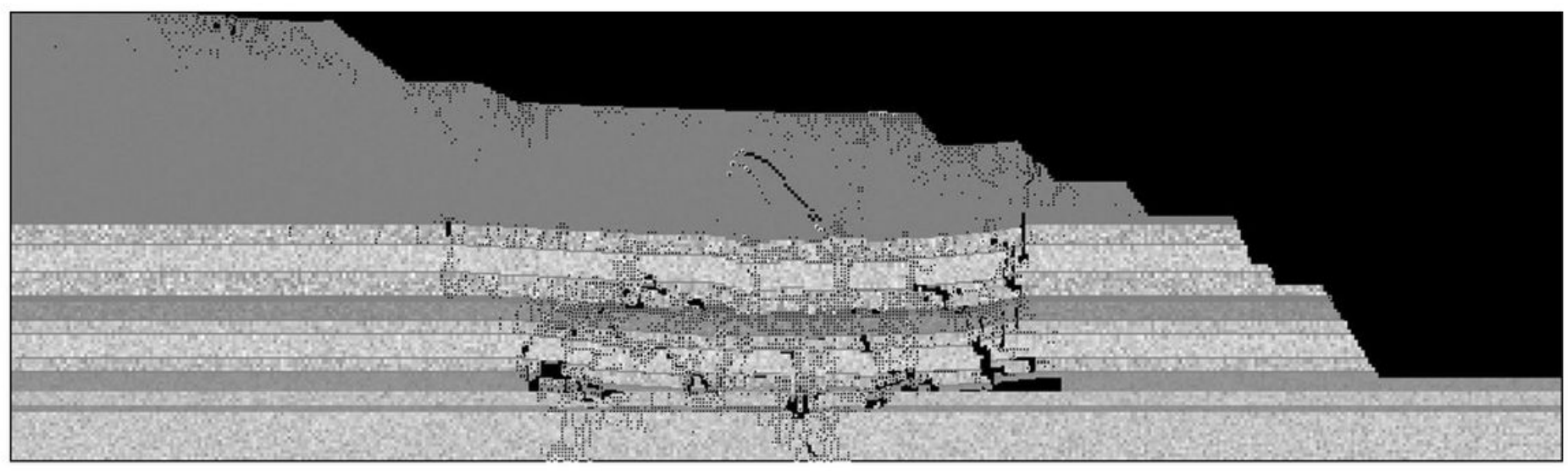

(a)

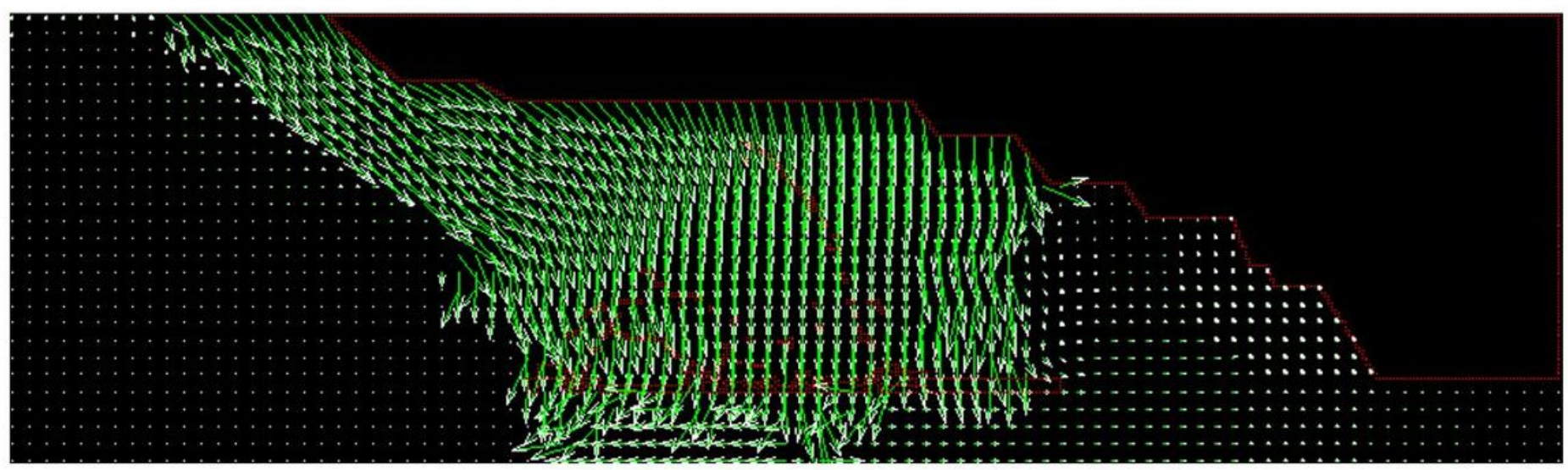

(b)

\section{Figure 5}

Characteristic of slope deformation and failure under along-slope mining: (a) rock mass collapse diagram; (b) displacement vector diagram

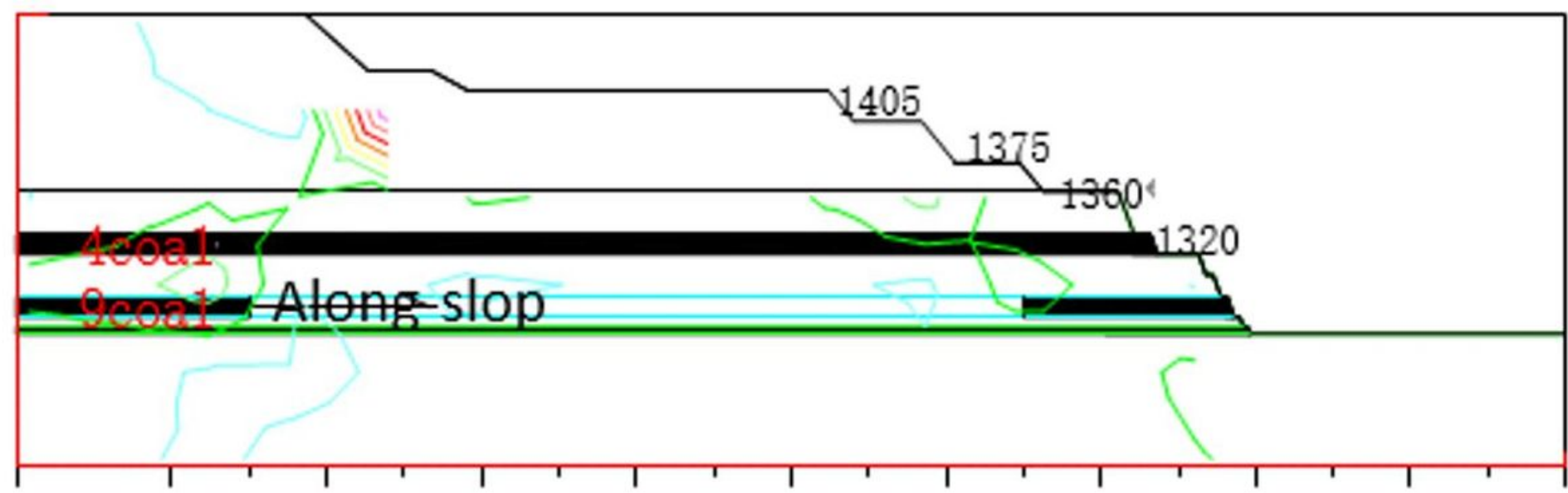

Figure 6

Stress contours of slope rock mass under along-slope mining 


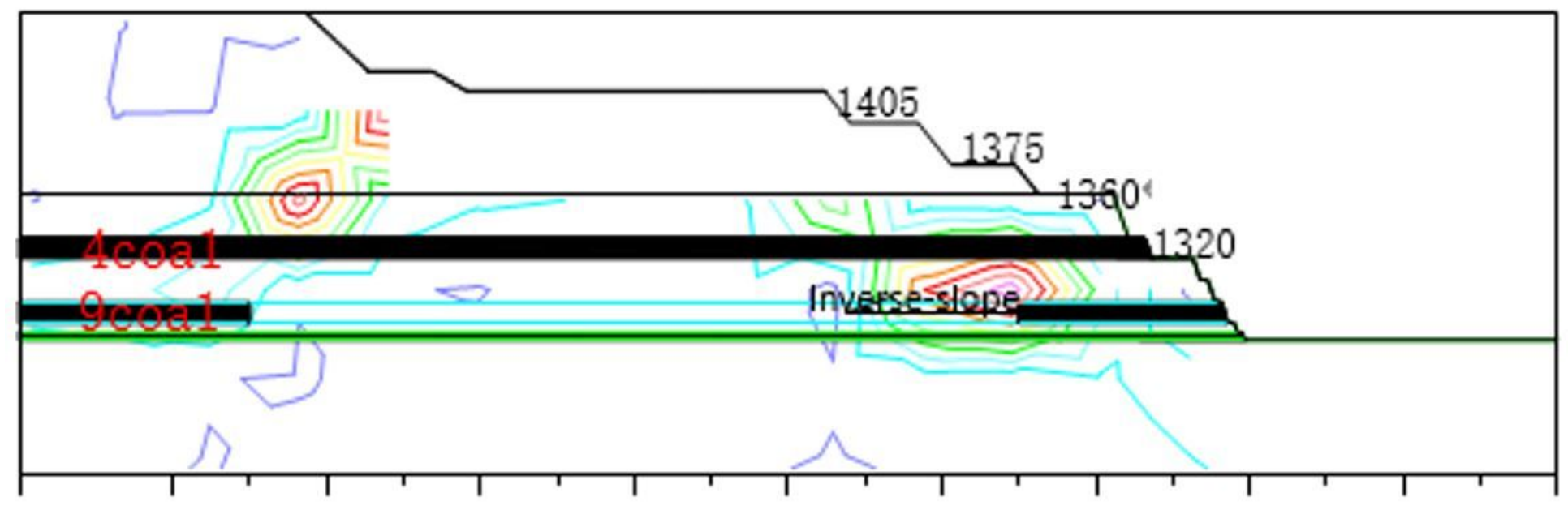

Figure 7

Stress contours of slope rock mass under inverse-slope mining

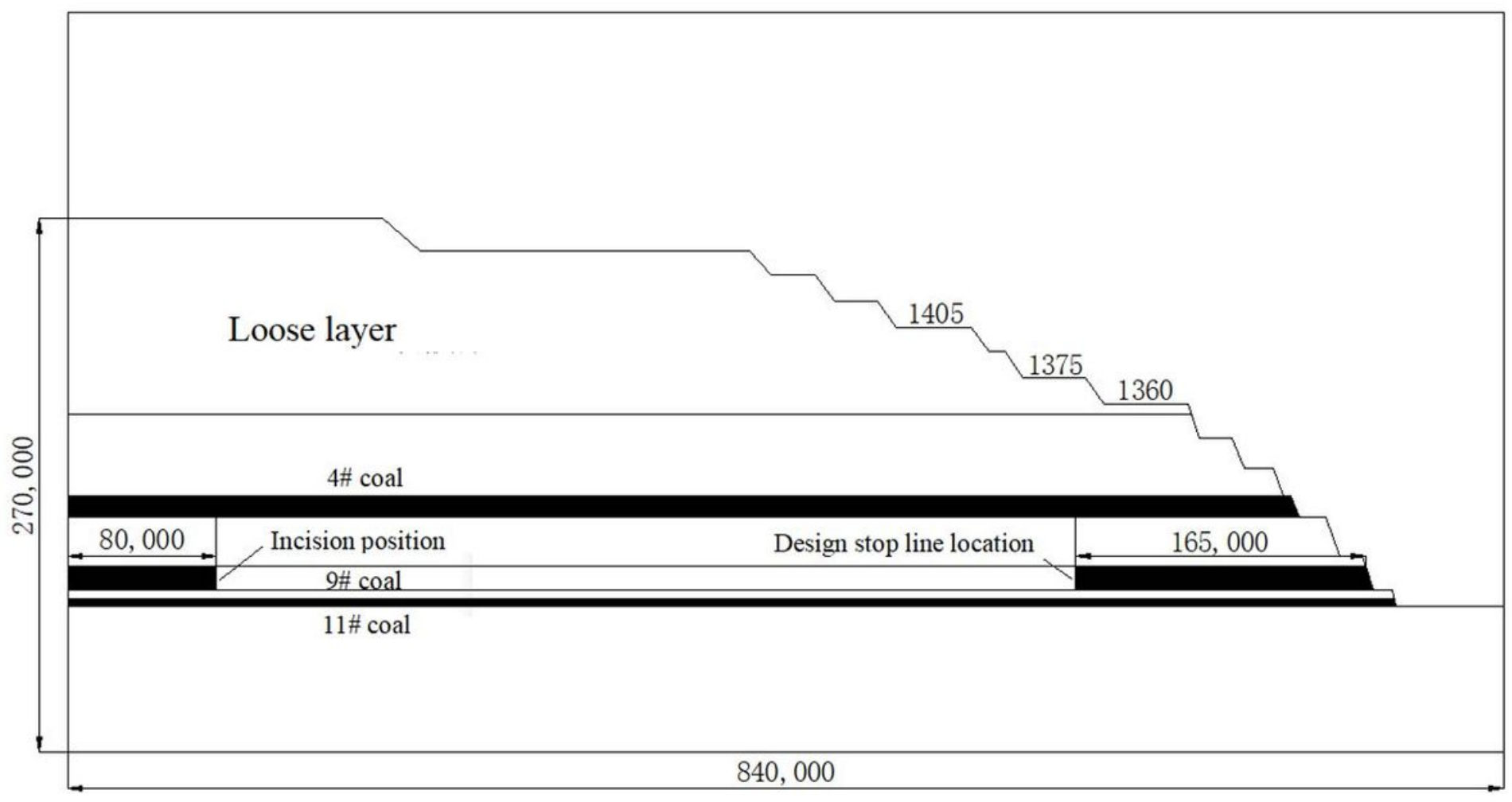

Figure 8

Schematic diagram of similar-material physical model for along-slope mining of No.9 coal seam 


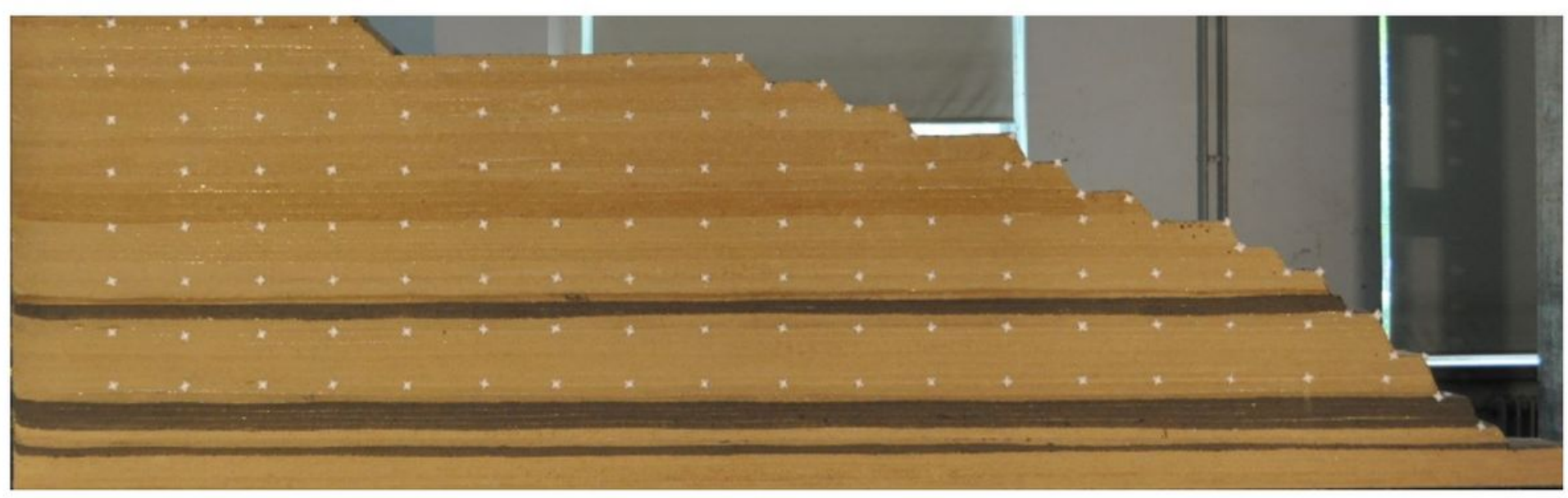

\section{Figure 9}

Physical model before underground mining

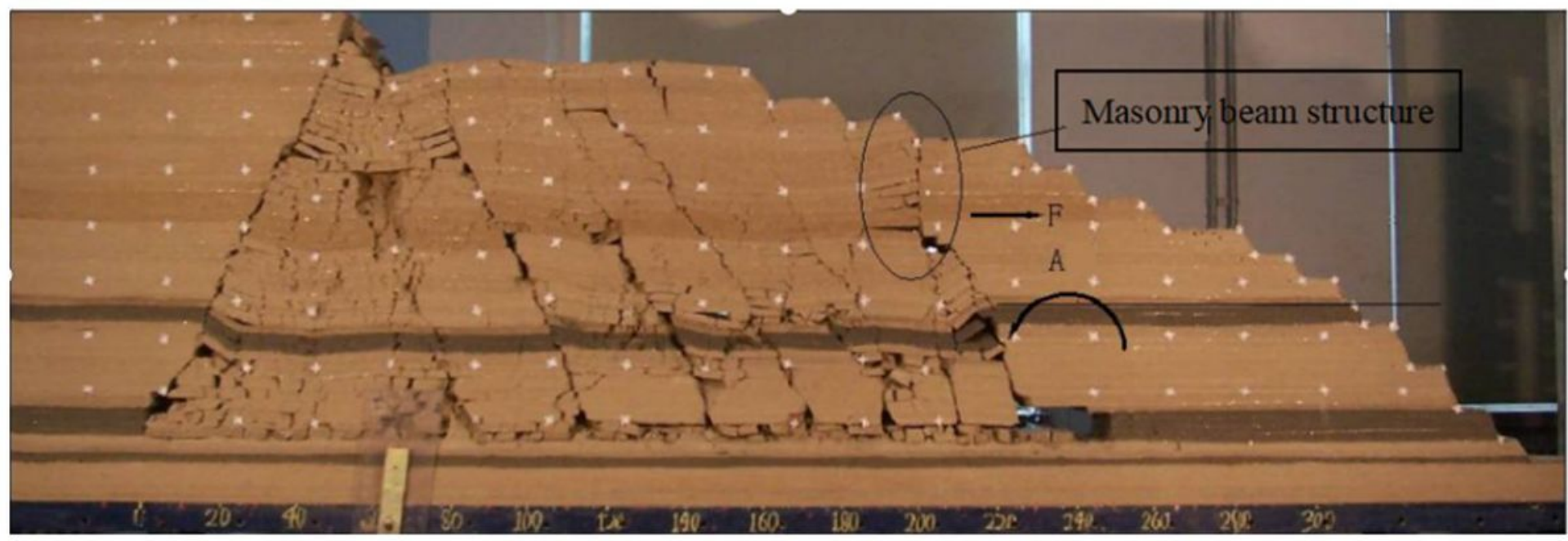

\section{Figure 10}

Physical model after along-slope mining to $500 \mathrm{~m}$

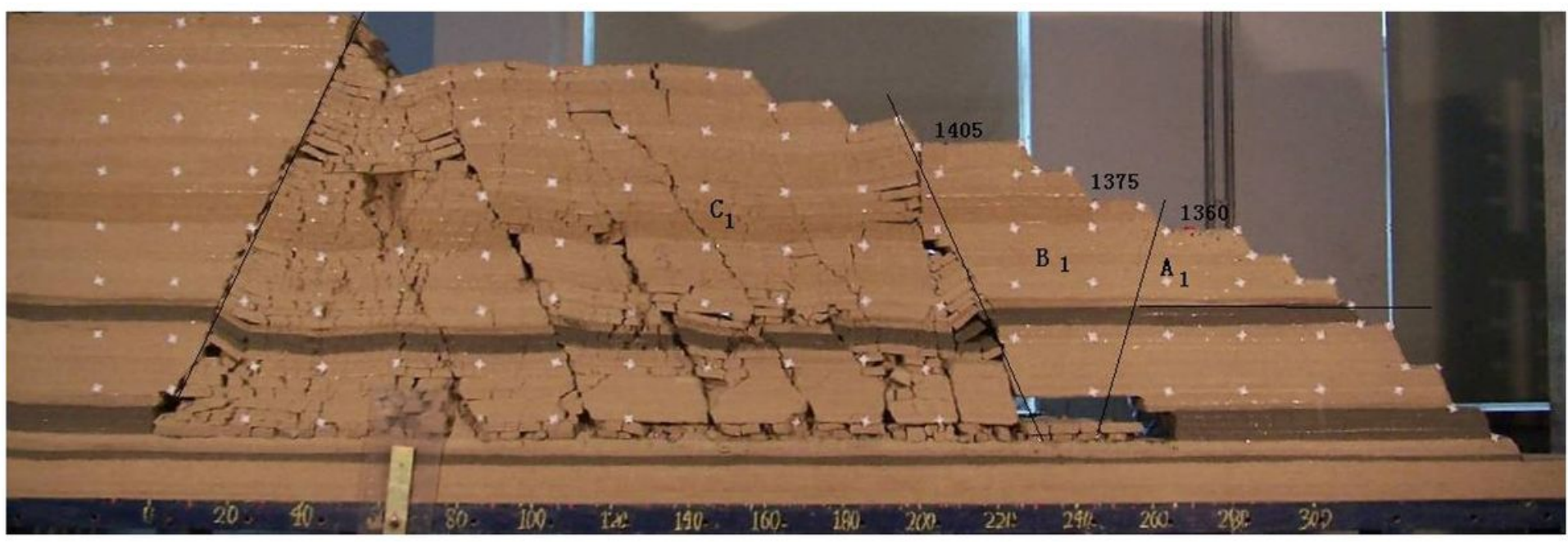




\section{Figure 11}

Physical model after along-slope mining to $545 \mathrm{~m}$

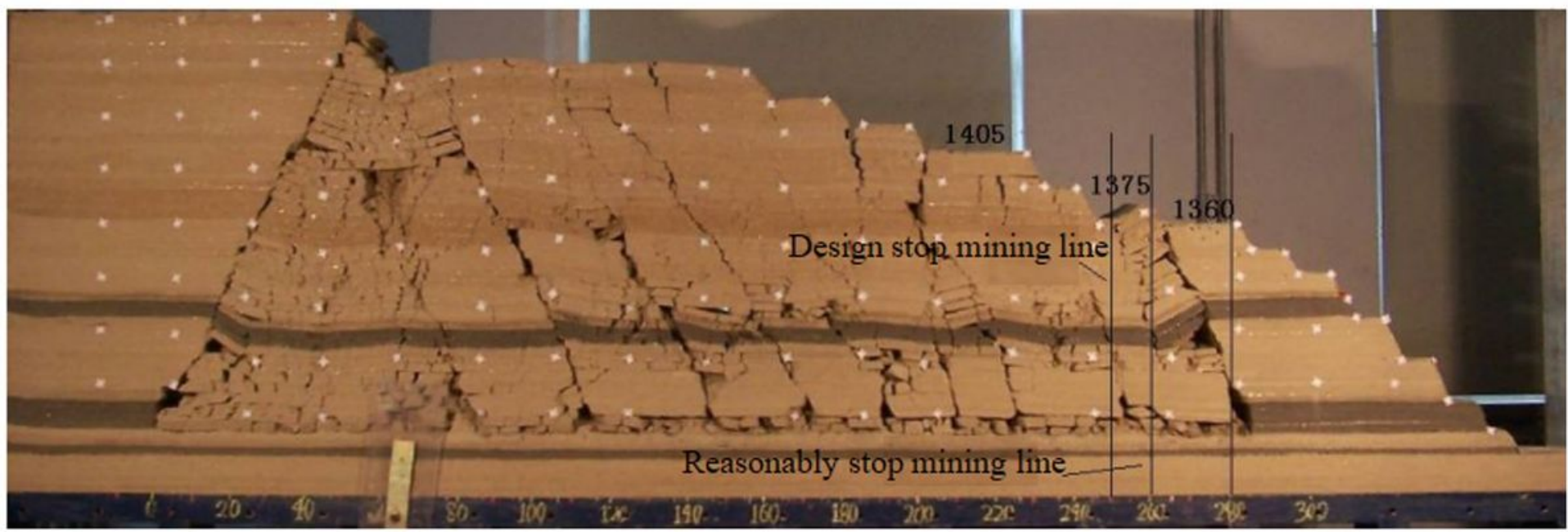

\section{Figure 12}

Physical model after along-slope mining to $560 \mathrm{~m}$

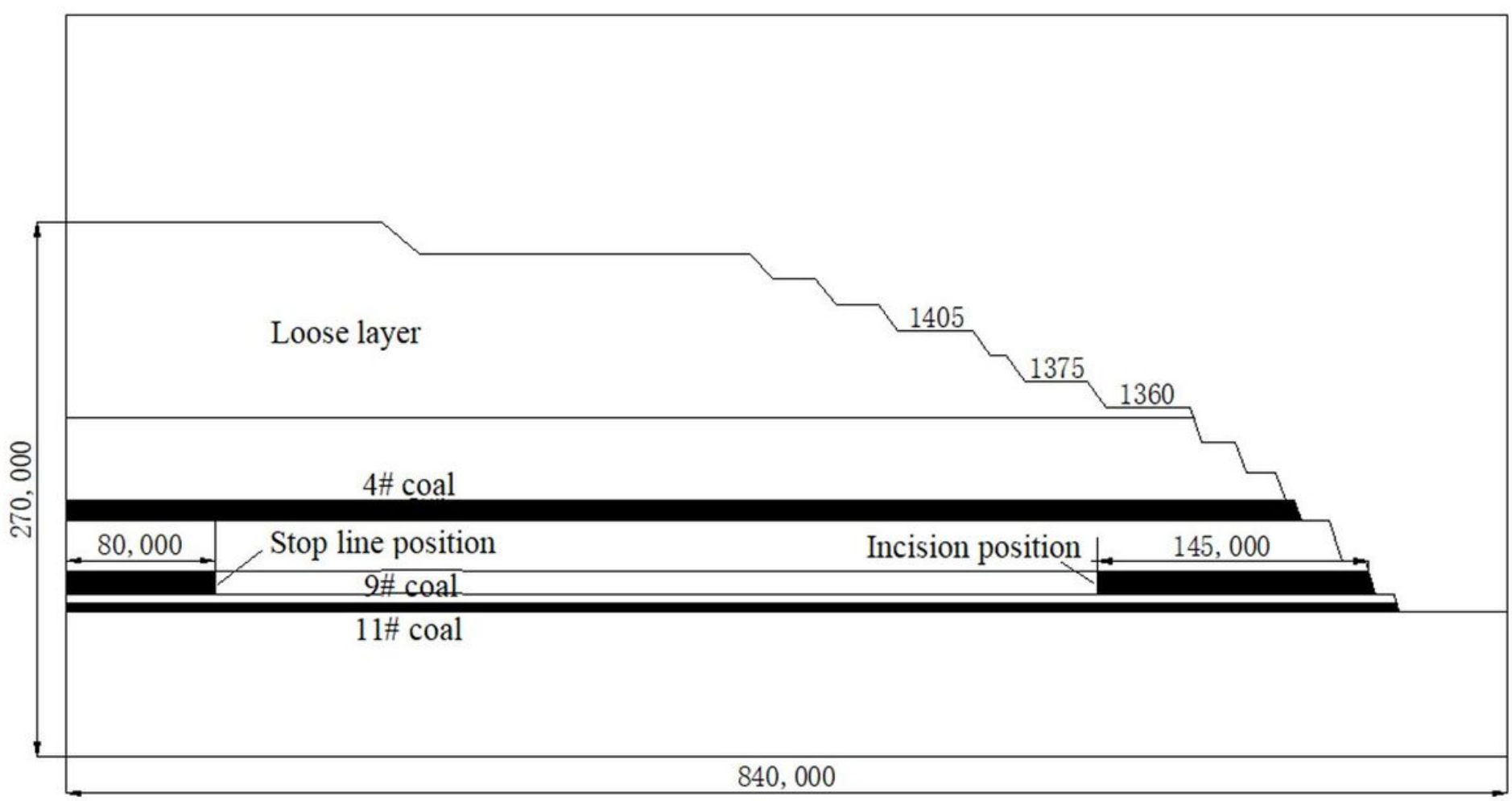

Figure 13

Schematic diagram of similar-material physical model for inverse-slope mining of No.9 coal seam 


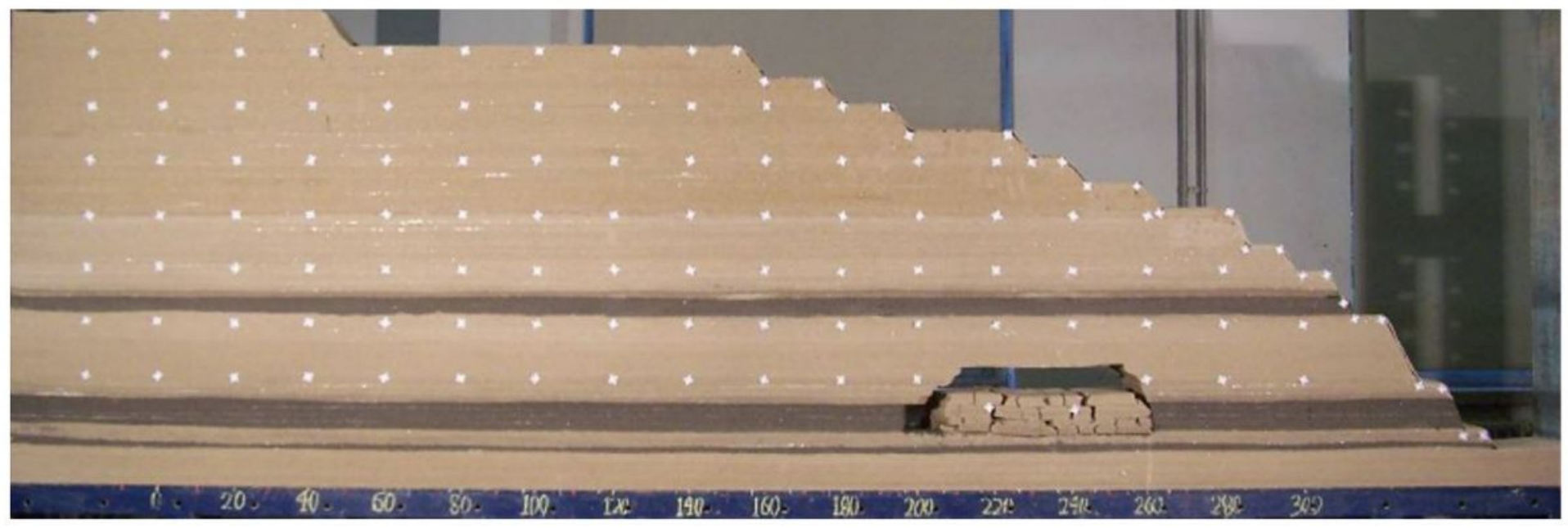

\section{Figure 14}

Physical model after inverse-slope mining to $130 \mathrm{~m}$

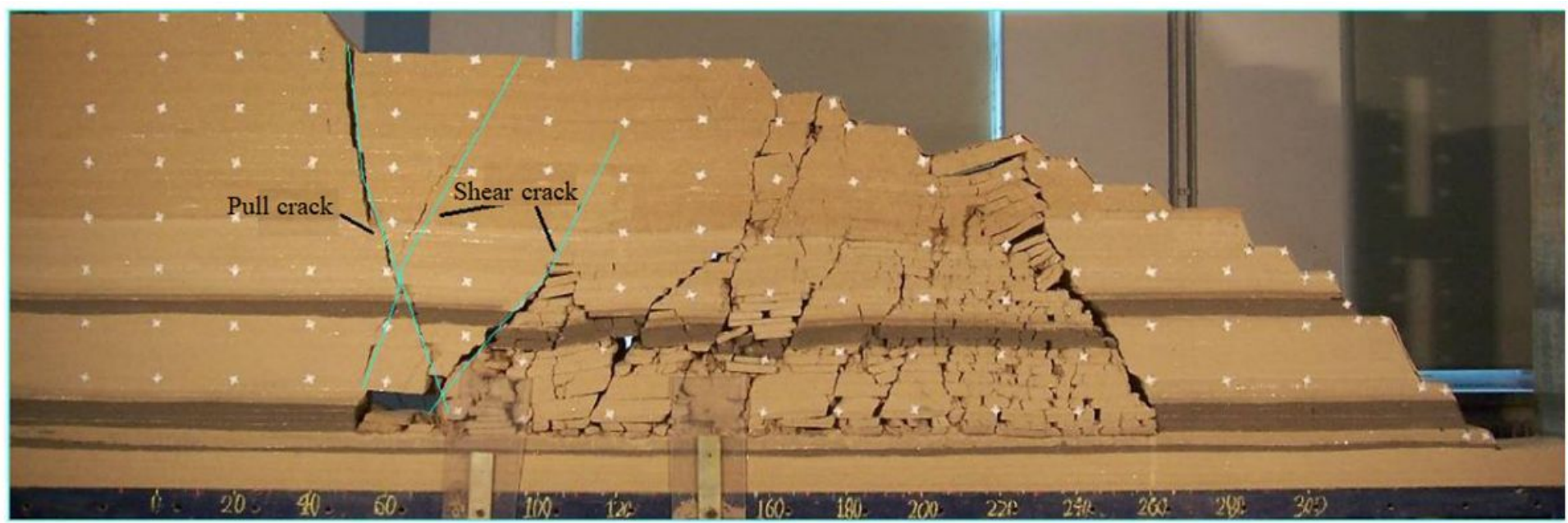

\section{Figure 15}

Physical model after inverse-slope mining to $470 \mathrm{~m}$

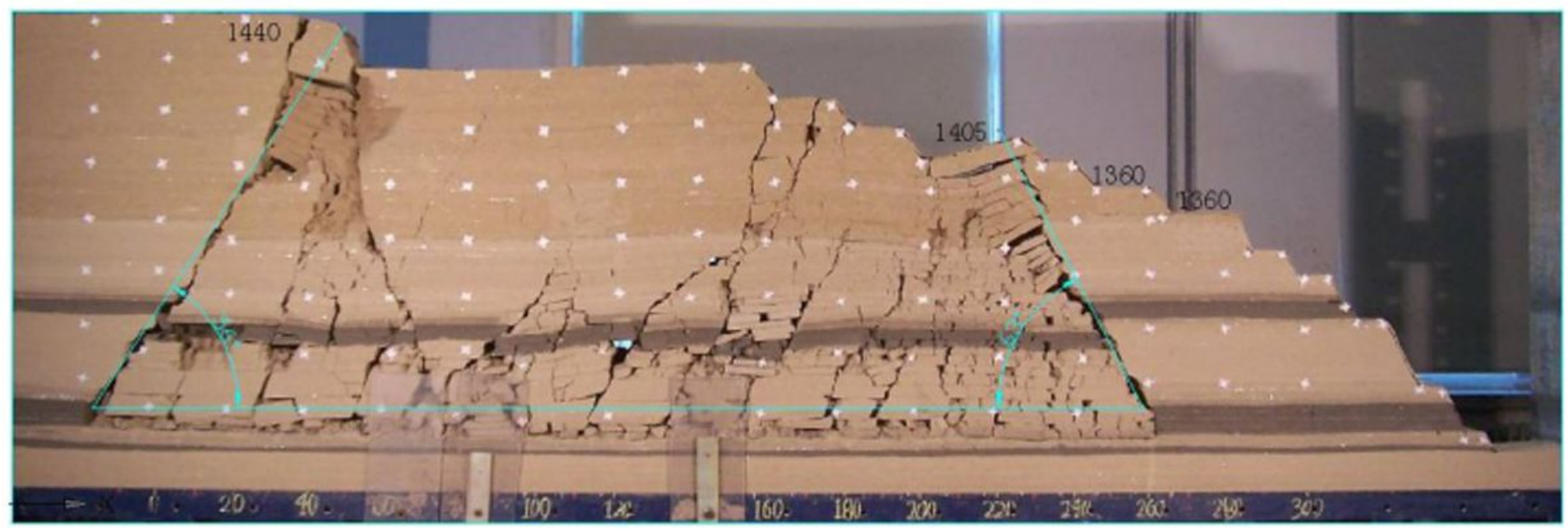


Figure 16

Physical model after inverse-slope mining to $560 \mathrm{~m}$

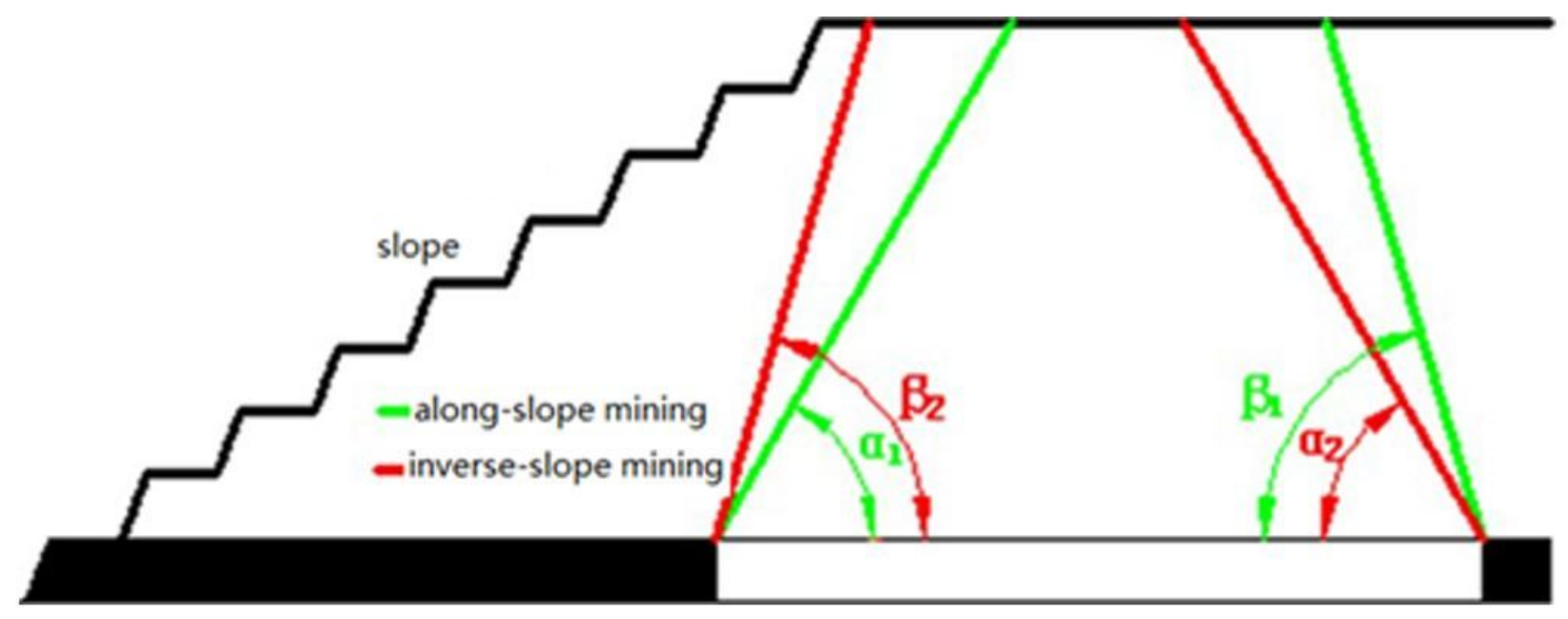

(a)

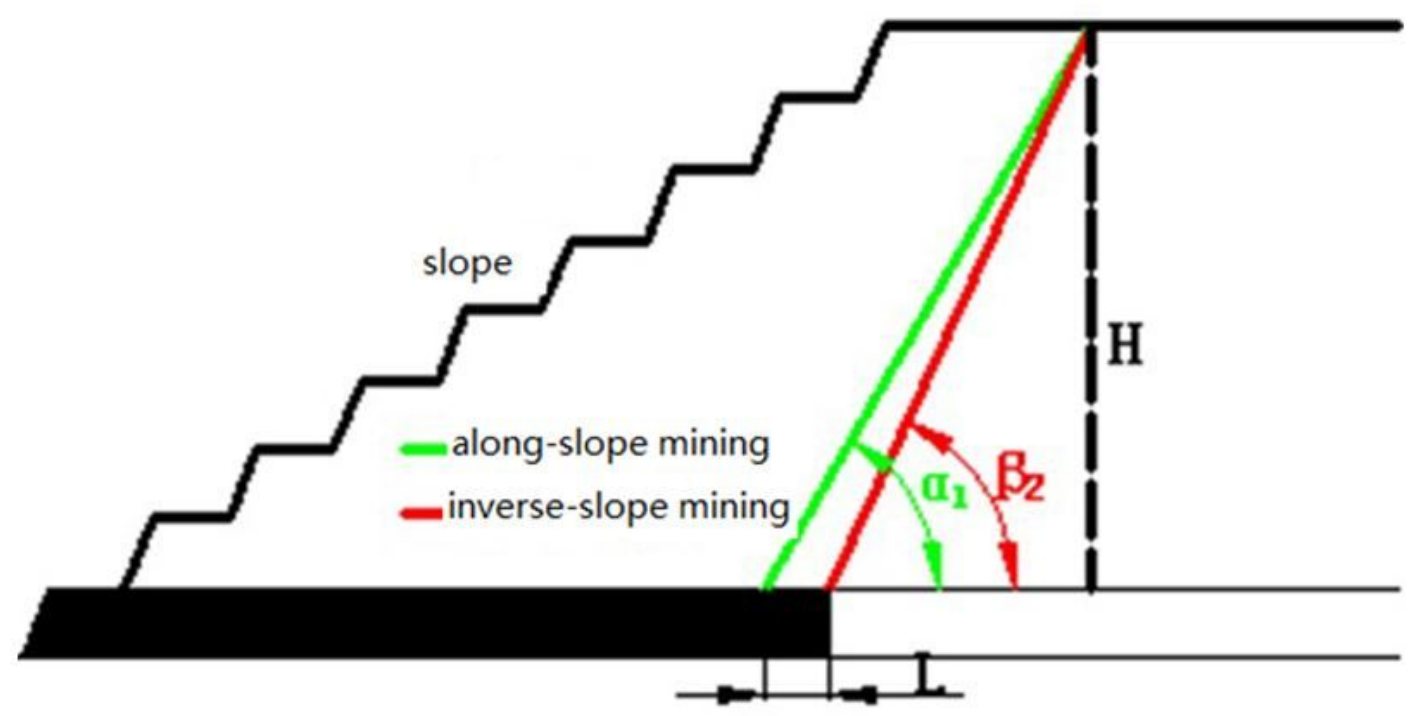

(b)

Figure 17

Influence on boundary parameters of different mining directions 